\title{
Endemic birds and protected area development on the Da Lat Plateau, Vietnam
}

\author{
JONATHAN C. EAMES
}

\section{Summary}

A study of Thuong Da Nhim and Chu Yang Sin Nature Reserves - identified as priority sites because located within the Da Lat Plateau Endemic Bird Area (EBA) in Vietnam was conducted between 10 November 1993 and 1 February 1994. A total of 212 bird species, of which 11 are considered globally threatened (including the rediscovered Grey-crowned Crocias Crocias langbianis), were recorded in the reserves. Eight restricted-range species were recorded, including the four species confined to the EBA. These two reserves are of international importance because they jointly support bird communities representative of the EBA. They are also of great economic importance, being within watersheds. Their extent is believed adequate but it is not known if they encompass all representative habitats over the full altitudinal range. Local tribal communities traditionally practise shifting cultivation, which has greatly modified the extent, composition and quality of evergreen forest and is causing its increasing fragmentation. Deliberate fires are preventing the regeneration of evergreen forest and promoting the growth of a climax dominated by Pinus kesiya. This reduces bird diversity and compromises the future of the endemic bird taxa. Other threats include recent logging activities, human immigration, the urban expansion of Da Lat and consequent increasing demand for charcoal and fuelwood. The Ministry of Agriculture and Rural Development should urgently proceed with the production of management plans for these areas, aiming to create a single, enlarged protected area. The primary land-use management strategy should be to conserve remaining areas of evergreen forest and to increase their extent by boundary realignment, elimination of shifting cultivation and fire, and the introduction of sympathetic forestry practices.

\section{Introduction}

BirdLife International has prioritized biological "hotspots", termed Endemic Bird Areas (EBAs), for conserving global biodiversity using birds as indicators of overall endemism (ICBP 1992). Three EBAs have been identified in Vietnam: the Annamese Lowlands and the Da Lat Plateau, each with four endemic restricted-range bird species, and the South Vietnamese Lowlands (previously termed Cochinchina [ICBP 1992]), with two endemic restricted-range species.

To date six national parks, 28 nature reserves, five historical and cultural reserves and two unclassified areas have been designated in Vietnam, totalling $10,945 \mathrm{~km}^{2}$ (Collins et al. 1991). Two areas have been designated for protected area development in the Da Lat Plateau EBA: Thuong Da Nhim (comprising Nui Ba-Nui Bi Doup and Phuc Binh sectors) and Chu Yang Sin Nature Reserves. 
A management feasibility study of Thuong Da Nhim and Chu Yang Sin Nature Reserves was undertaken between 10 November 1993 and 1 February 1994 (Eames and Nguyen Cu 1994). Specifically, fieldwork in Thuong Da Nhim Nature Reserve was undertaken around Hill $197^{8}\left(12^{\circ} 02^{\prime} \mathrm{N} 108^{\circ} 42^{\prime} \mathrm{E}\right)$, Ninh Tuan province, and on Nui Bi Doup $\left(12^{\circ} \mathrm{O} 5^{\prime} \mathrm{N} 108^{\circ} 40^{\prime} \mathrm{E}\right)$ and Nui Gia Rich $\left(12^{\circ} \mathrm{O} 8^{\prime} \mathrm{N}\right.$ $108^{\circ} 42^{\prime} \mathrm{E}$ ), Lam Dong province. In Chu Yang Sin Nature Reserve fieldwork was carried out around Chu Yang Sin $\left(12^{\circ} 24^{\prime} \mathrm{N} 108^{\circ} 26^{\prime} \mathrm{E}\right)$, Dak Lak province (Figure 1). The aim of the work was to assist the Ministry of Forestry in surveying and developing management plans for Thuong Da Nhim and Chu Yang Sin. The primary objectives of the field survey were to: (1) assess the conservation value of the proposed nature reserves; (2) identify constraints on the development of the proposed nature reserves; and (3) develop modified management proposals.

This paper considers the development of existing protected areas on the Da Lat Plateau in relation to their importance for globally threatened and restricted-range birds and makes recommendations for the modification of existing proposals.

\section{The study area}

\section{The Da Lat Plateau Endemic Bird Area}

Eight restricted-range species have been recorded in the Da Lat Plateau EBA (Table 1). The global ranges of four bird species (Grey-crowned Crocias Crocias langbianis, Black-hooded Laughingthrush Garrulax milleti, Collared Laughing-

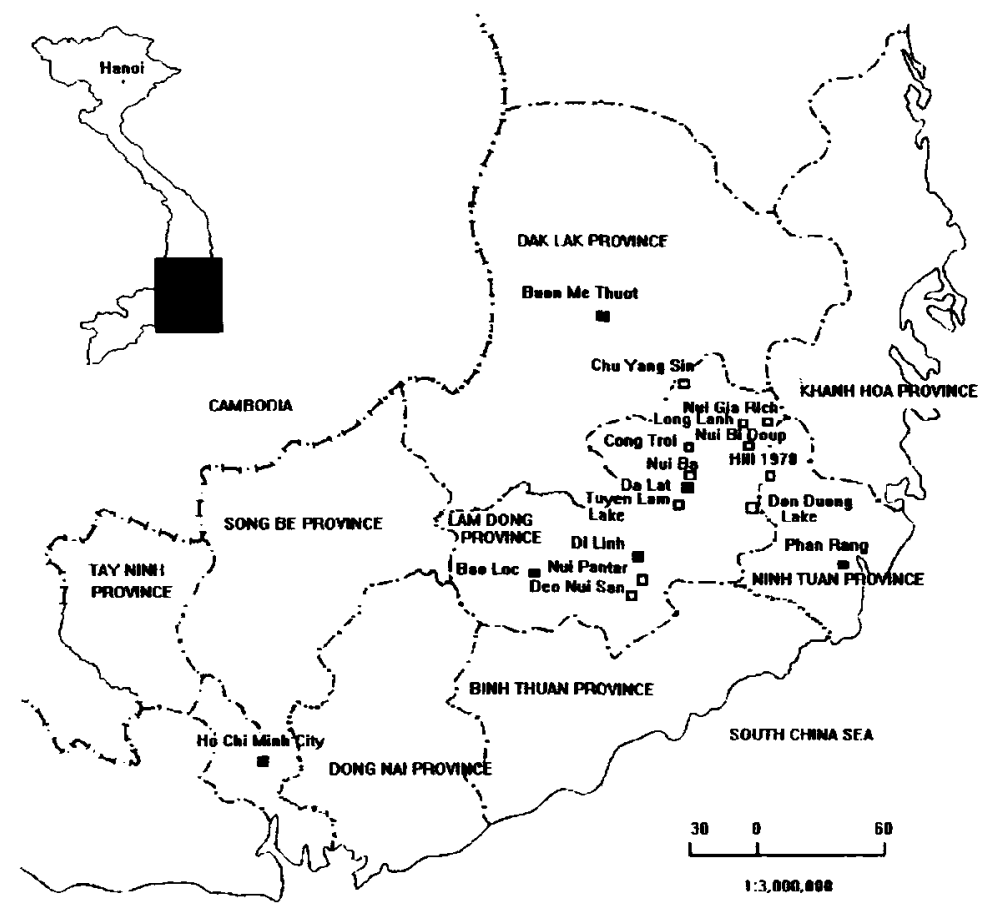

Figure 1. Location of key places mentioned in the text. 
Table 1. Habitat requirements of restricted-range birds on the Da Lat Plateau EBA.

\begin{tabular}{|c|c|c|c|c|}
\hline Species & Status & Threat & Altitude $(\mathrm{m})$ & Habitat \\
\hline Rheinardia ocellata & & $\mathrm{V}$ & up to 1,500 & Evergreen forest \\
\hline Crocias langbianis & E & C & $900-1,200$ & Evergreen forest \\
\hline Garrulax milleti & E & $\mathrm{V}$ & $900-1,500$ & $\begin{array}{l}\text { Evergreen forest } \\
\text { including } \\
\text { secondary growth }\end{array}$ \\
\hline Garrulax vassali & & LR & $600-2,900$ & $\begin{array}{l}\text { Evergreen forest } \\
\text { including } \\
\text { secondary growth }\end{array}$ \\
\hline Garrulax yersini & E & $\mathrm{V}$ & $1,500-2,300$ & $\begin{array}{l}\text { Evergreen forest } \\
\text { including } \\
\text { secondary growth }\end{array}$ \\
\hline Jabouilleia danjoui & & $\mathrm{v}$ & $1,500-2,290$ & $\begin{array}{l}\text { Evergreen forest } \\
\text { including } \\
\text { secondary growth }\end{array}$ \\
\hline Sitta solangiae & & V & $1,700-2,100$ & $\begin{array}{l}\text { Evergreen forest; } \\
\text { logged forest }\end{array}$ \\
\hline Carduelis monguilloti & E & NT & $1,000-1,800$ & $\begin{array}{l}\text { Pine and mixed } \\
\text { forest orchards } \\
\text { and cultivation }\end{array}$ \\
\hline
\end{tabular}

Threat category: C, Critical; V, Vulnerable, NT, Near-threatened; LR, Low Risk (Collar et al. 1994 and M. J. Crosby in litt. 1994); E, Endemic to Da Lat Plateau EBA.

thrush G. yersini and Vietnamese Greenfinch Carduelis monguilloti) are confined to this EBA. In addition some 25 subspecies are confined to the EBA, while a further 35 occur as restricted-range subspecies but with wider distributional ranges in Indochina (Cambodia, Laos, Thailand and Vietnam) (Appendix 1). Seven of the eight restricted-range species inhabit evergreen forest, whilst Vietnamese Greenfinch occurs in mixed and evergreen forest (Table 1).

Evidence of congruence in endemism amongst other vertebrates is generally deficient, but is shown by several plant species including Pinus dalatensis, $P$. krempfii, Colobogyne langbianensis, Elaeocarpus bidoupensis, Rhododendron langbianense, Quercus briaianensis, and several species of Orchidaceae including Agrostophyllum brevipes and Bulbophyllum evrardii.

\section{Biogeography and geographical location}

Biogeographically the Da Lat Plateau has been included in the Indochinese Rainforest (Udvardy 1975), South Indochina Sector (Vidal 1960) and South Indochina (MacKinnon and MacKinnon 1986). The Thuong Da Nhim and Chu Yang Sin Nature Reserves are located in unit VII for Indochina proposed by Schmid (Campbell and Hammond 1989) and as a distinct biounit, the Da Lat Highlands, by MacKinnon (1993).

Thuong Da Nhim Nature Reserve is located in Lac Duong district in northern Lam Dong province and in Phuoc Binh district of northern Ninh Thuan province. Chu Yang Sin Nature Reserve is located in Krong Bong and Lac districts in southern Dak Lak province (Figures 1 and 2). The total protected area is contained within the quadrangle represented by the loci $11^{\circ} 45^{\prime} \mathrm{N} 108^{\circ} 17^{\prime} \mathrm{E}$ to $12^{\circ} 30^{\prime} \mathrm{N} 108^{\circ} 17^{\prime} \mathrm{E}$ to $12^{\circ} 30^{\prime} \mathrm{N} 108^{\circ} 45^{\prime} \mathrm{E}$ to $11^{\circ} 45^{\prime} \mathrm{N} 108^{\circ} 45^{\prime} \mathrm{E}$. Figure 2 shows the 


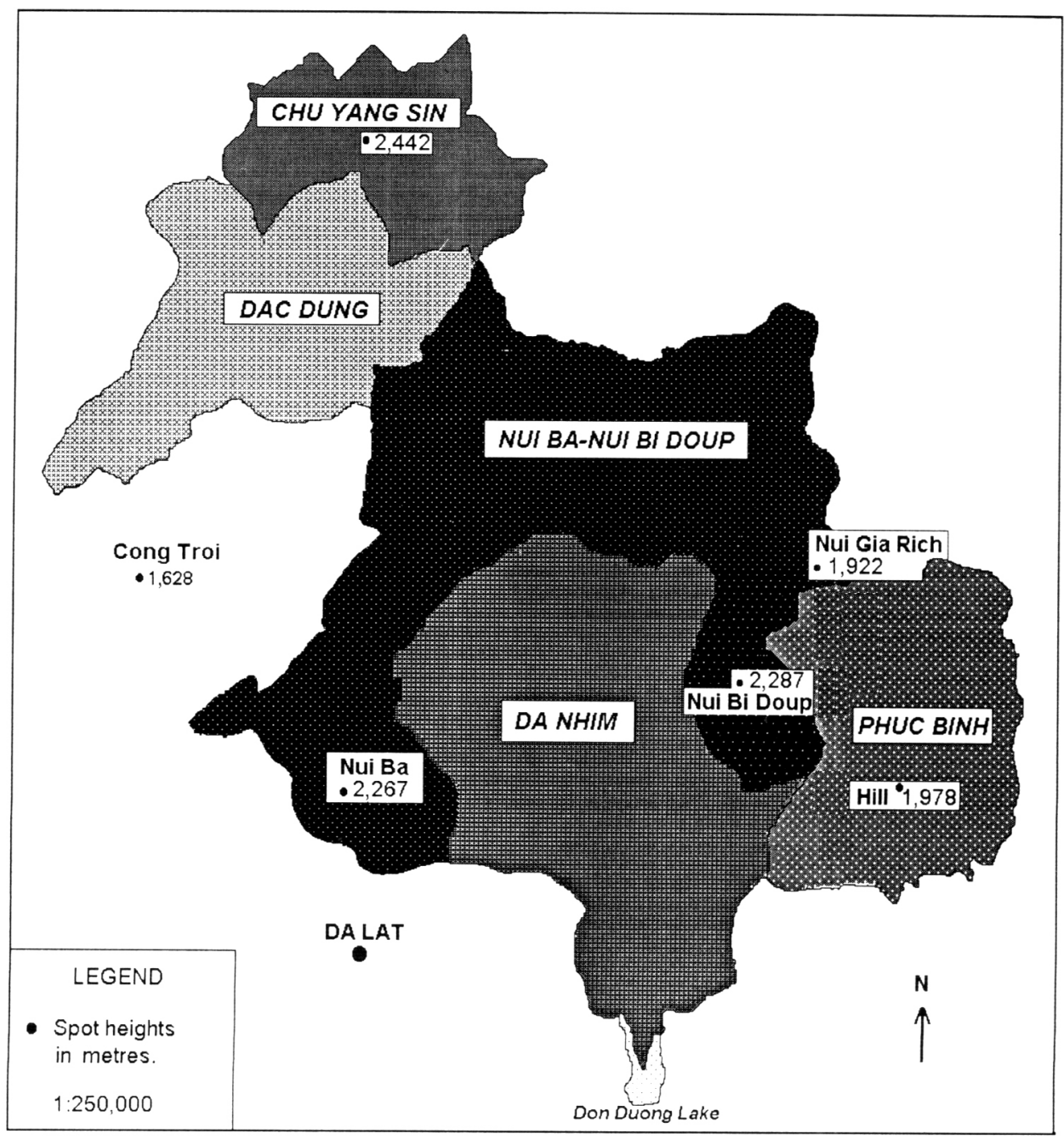

Figure 2. Current boundaries of Chu Yang Sin and Thuong Da Nhim Nature Reserves. Thuong Da Nhim Nature Reserve comprises Nui Ba-Nui Bi Doup and Phuc Binh sectors.

relative juxtaposition of the reserve boundaries, together with the $\mathrm{Da}$ Nhim Watershed Protection Forest and Dac Dung Special Use Forest.

\section{Date of establishment}

The Thuong Da Nhim and Chu Yang Sin Nature Reserves were established on 9 August 1986 by Council of Ministers decision number 194/CT, under which most of the national protected area system was established. Under the existing proposals advanced by the provincial governments, the Nui Ba-Nui Bi Doup sector of the Thuong Da Nhim Nature Reserve in Lam Dong province covers 71,850 ha. The Phuoc Binh sector of the Thuong Da Nhim Nature Reserve in Ninh Thuan province covers 25,866 ha. The Chu Yang Sin Nature Reserve 
covers C.20,000 ha in Dak Lak province (MacKinnon 1990). This gives a combined area of c.117,716 ha. Further details are in Eames and Nguyen Cu (1994).

\section{Topography}

The area comprises a mountainous plateau forming the southern edge of the western highlands (Figures 1 and 2). The elevation change is great with a range of $2,042 \mathrm{~m}\left(400-2,44^{2} \mathrm{~m}\right)$ in southern Dak Lak and a range of $1,987 \mathrm{~m}$ (300$2,287 \mathrm{~m}$ ) from southern Ninh Thuan to the summit of Nui Bi Doup. The area is dominated by several peaks over two thousand metres including Chu Yang Sin $(2,442 \mathrm{~m})$, Chu Yang $\mathrm{K}^{\prime} \mathrm{Lih}(2,098 \mathrm{~m})$, Nui Bi Doup $(2,287 \mathrm{~m})$ and Nui Ba also known as Mount Lang Bian $\left(12^{\circ} \mathrm{O} 2^{\prime} \mathrm{N} 108^{\circ} 26^{\prime} \mathrm{E}\right)(2,267 \mathrm{~m})$. The outlying peaks of Chu Yang Sin and Chu Yang K'Lih are situated on the northward fringe of the plateau. In the north/central part of the plateau elevation drops to $500-1,000 \mathrm{~m}$, whereas in the south/central part of the plateau elevation ranges from $1,000-2,000 \mathrm{~m}$.

The underlying strata comprise granites and dacites for the mountains, schists and sandstones in hill districts, and basalts for the tablelands (Campbell and Hammond 1989). The soils of the area may be classified into four types. Most of the plateau is covered with a complex composed of mostly red and yellow podzolic and lithosolic soils. In the upper $\mathrm{Da}$ Nhim watershed, including Nui Bi Doup, Nui Gia Rich and the area around Nui Ba, soils are composed of red and yellow podzols on acid rocks. In the middle reaches of the Dak Krong Kap there are red and yellow podzolic soils on old alluvial sediments. In the upper Krong Ana on the northern edge of the plateau there are red and yellow podzolic soils on acid rocks and a complex of podzolic soils on old alluvial sediments and alluvial soils (Moorman 1961).

There are two major watersheds on the Da Lat Plateau. The streams in the southern part of the plateau drain south into the Da Nhim River. Although the $\mathrm{Da}$ Nhim has been dammed at $11^{\circ} 51^{\prime} \mathrm{N} 108^{\circ} 36^{\prime} \mathrm{E}$ to form Don Duong Lake (Figures 1 and 2), the river continues to flow south-west and joins the Da Dung River which eventually joins the Dong Nai River. To the north, Chu Yang Sin lies in the watershed of the Ea K'Tour which flows north and thence into the Ea Krong Ana, whereas streams to the south of Chu Yang Sin flow into the Dak Krong Kno River. Both the Ea Krong Ana and the Dak Krong Kno eventually join the Serepok River which drains into the Mekong basin in Cambodia.

\section{Climate}

The area enjoys a tropical monsoon climate and is affected by the south-west monsoon, with rainfall from June to December. Rainfall is heaviest on the southern rim of the plateau, with an annual mean of $2,876 \mathrm{~mm}$ at Bao Loc, decreasing on a south-to-east gradient; thus to the east of the plateau at Phan Rang mean annual rainfall is a mere $789 \mathrm{~mm}$. The number of rain-days decreases on a south-to-north gradient; thus Bao Loc has a mean 199 rain-days while Buon Me Thuot has 138 . In other words the monsoon is shorter in the north and east 
of the region. Temperature is higher in the north and east of the plateau, with a mean daily $24.2^{\circ} \mathrm{C}$ at Buon Me Thuot and $26^{\circ} \mathrm{C}$ at Phan Rang. The lowest daily temperatures are experienced at $\mathrm{Da}$ Lat $\left(0.6^{\circ} \mathrm{C}\right)$ and at Bao Loc $\left(4.2^{\circ} \mathrm{C}\right.$ ) (Pham Ngoc Toan and Phan Tat Dac 1978).

\section{Vegetation}

The natural vegetation of the Da Lat Plateau has been classified as Pine Forest, Tropical Montane Evergreen Forest, and Lowland Semi-Evergreen Forest (MacKinnon and MacKinnon 1986). In the broadest, most general classification, the original vegetation of the Da Lat Plateau comprised formations of tropical moist forests, specifically tropical lower montane rainforest and tropical upper montane rainforest. Within these formations, three floristic zones are represented: Upper dipterocarp, Oak-laurel and Montane ericaceous (Whitmore 1992).

On Chu Yang Sin the Upper dipterocarp floristic zone extends from 500 to 1,000 $\mathrm{m}$ and includes species of Anizoptera, Dipterocarpus, Hopea, Shorea and Parashorea. This floristic zone is not represented on Nui Bi Doup and Nui Gia Rich. Throughout the Da Lat Plateau the Oak-laurel floristic zone is very broad with the first Fagaceae and Lauraceae appearing at 1,000 $\mathrm{m}$ on Chu Yang Sin and these genera extend to the summit at $2,442 \mathrm{~m}$. Within the Fagaceae, species within the genera Castanopsis, Lithocarpus and Quercus are numerous. Appearing within this zone is the most extensive seral forest type; growing in single species stands is Pinus kesiya, covering an estimated 120,000 ha (Shiva 1990). Other Coniferae appear above c.1,500 m, and include two species of Pinaceae, Pinus dalatensis and $P$. krempfii, and a representative of the Cupressaceae, Fokinia hodginsii. The Montane ericaceous zone features Ericaceae, represented by several genera including Rhododendron, and Myrtaceae, featuring several Syzygium species.

As a result of human use, climatic seasonality, aspect and soil, floral composition and structure varies greatly to produce mosaics of different forest types within these broad formations. Figure 3 shows the different vegetation types, the extent and predominance of Pinus kesiya in the southern part of the area, and the degree to which the evergreen forest has become fragmented.

\section{Human population and land use}

In the Nui Ba-Nui Bi Doup sector of Thuong Da Nhim Nature Reserve the total human population has been estimated at 10,057 individuals and composed of 1,402 families, comprising four ethnic groups. The mean human population density is 14 individuals per $\mathrm{km}^{2}$, with a mean annual population growth rate of 2.3\% between 1991 and 1995 (Lam Dong Forest Protection Department in litt.). According to Ninh Thuan Forest Protection Department, there are no people living in Phuoc Binh sector of Thuong Da Nhim Nature Reserve in Ninh Thuan province. There are no longer any permanent villages inside Chu Yang Sin Nature 


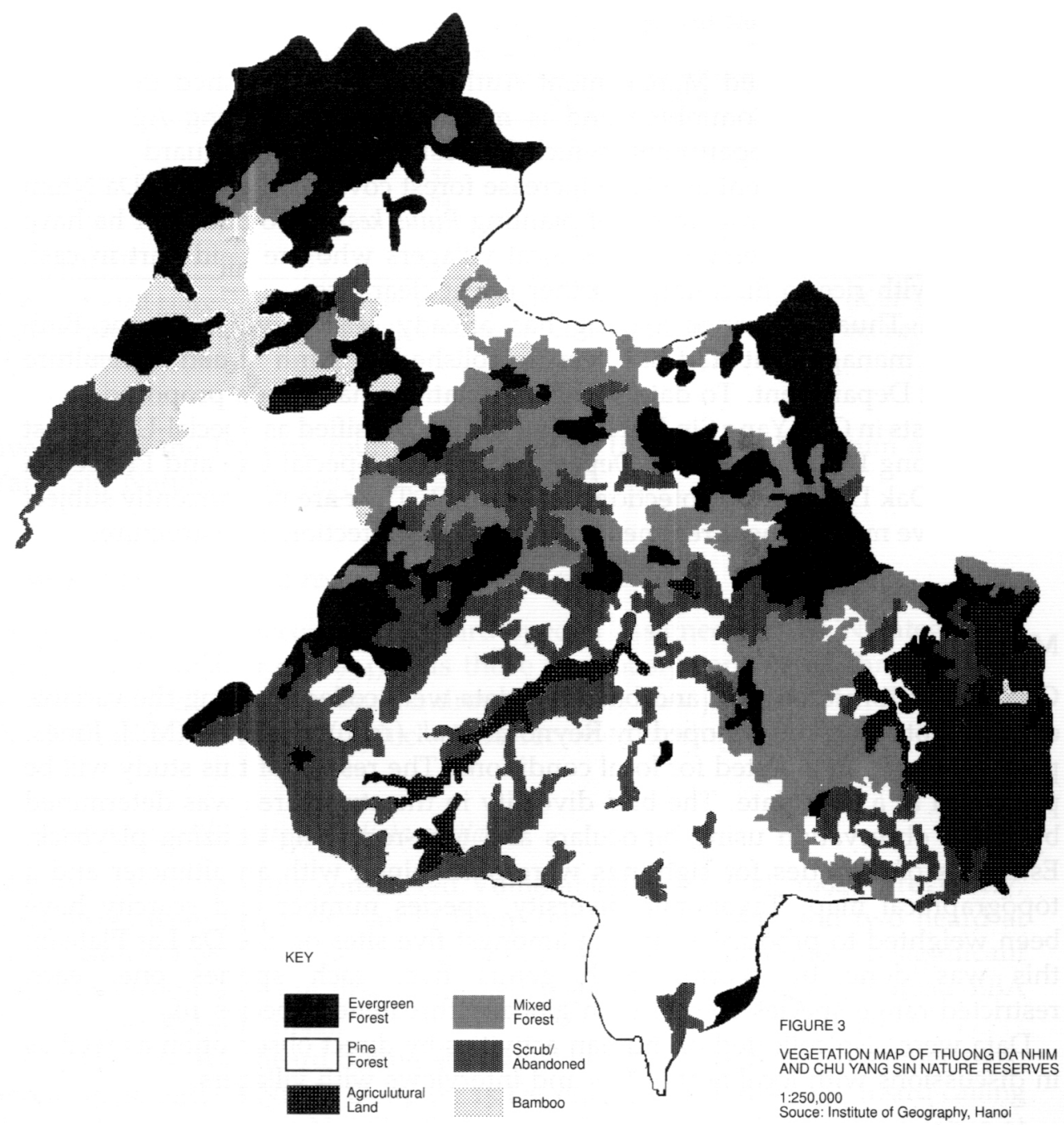

Figure 3. Vegetation map of Thuong Da Nhim and Chu Yang Sin Nature Reserves. (Source: Institute of Geography, Hanoi.)

Reserve and the nearest settlement is outside the protected area at Chu Pui commune.

The tribal minority groups living in the Nui Ba-Nui Bi Doup sector of Thuong Da Nhim practise shifting cultivation. In their gardens or swiddens they cultivate hill rice and also grow manioc, maize, tobacco, squash, chillies and potatoes. They supplement their diet with a variety of animal and vegetable products garnered from the forest. As a result of government policy some communities have now been settled and practise wet-rice cultivation in valley bottoms. At some villages people participate in the cash economy by producing charcoal from hardwood tree species baked in ovens dug in the forest floor. Women at Long Lanh collect and sell some Orchidaceae species. There is also some cutting and sale of sawn hardwood planks. 


\section{Current management}

The Da Nhim watershed Management Authority was established in 1987 by Lam Dong People's Committee and is managed by Lam Dong Agriculture Forestry and Water Department, which has established three guard stations. The primary management aim is to increase forest cover in the upper Da Nhim watershed through a programme of planting Pinus kesiya. To date, 291 ha have been planted. The scheme employs local villagers who are paid part in cash and part with rice to discourage further forest clearance.

In Ninh Thuan province logging has already ceased and a Phuoc Binh watershed management staff has been established by Ninh Thuan Agriculture and Forest Department. To date two guard stations have been proposed.

The forests in Chu Yang Sin Nature Reserve are classified as Special-Use Forest by Lam Dong Forest Protection Department and as Special-Use and Protection Forest by Dak Lak Forest Protection Department. They are not currently subject to any active management regime and there is no protection infrastructure.

\section{Methods}

Quantitative ornithological and botanical data were collected using the variable circular plot method developed by Reynolds et al. (1980), modified (M. J. Jones, pers. comm.) and adapted for local conditions. The results of this study will be published at a later date. The bird diversity in the study area was determined by direct observation using binoculars and tape-recording utilizing playback. Estimates of altitudes for sightings were determined with an altimeter and a topographical map. Taxonomic diversity, species number and scarcity have been weighted to produce a ranking amongst five sites on the Da Lat Plateau: this was done by scoring each genus five, each species one, each restricted-range species 20 and each globally threatened species 10.

Data were also collected on human activities by direct observation as well as in discussions with local authorities and interviews with villagers.

\section{Results}

A total of 212 bird species were recorded in the Thuong Da Nhim and Chu Yang Sin Nature Reserves, of which 11 are considered globally threatened (Collar et al. 1994). Eight restricted range species were recorded, including the four species which are endemic to the Da Lat Plateau (ICBP 1992). In total, 61 of the 64 restricted-range bird taxa known from the Da Lat Plateau were recorded. Of particular note was the rediscovery of Grey-crowned Crocias Crocias langbianis which was only previously known from three specimens collected in 1938 (Gyldenstolpe 1939, Eames 1994, Eames et al. 1995b). A large population of a newly described taxon of Spectacled Fulvetta Alcippe ruficapilla bidoupensis was located on Chu Yang Sin (Eames et al. 1995a) and Black-hooded Laughingthrush was located at Nui Gia Rich and on Chu Yang Sin, thereby extending the species's known range. Appendix 2 provides a complete list of all birds recorded during the study. Table 2 provides a summary of the ranked bird diversity at 
Table 2. Bird diversity recorded at Thuong Da Nhim (Hill 1978 and Nui Bi Doup/Nui Gia Rich), Cong Troi, Nui Ba and Chu Yang Sin Nature Reserves.

\begin{tabular}{lrccccc}
\hline Location & Genus & Species & RRS $^{a}$ & RDB $^{b}$ & Score & Rank \\
\hline Hill 1978 & 74 & 93 & 5 & 5 & 613 & 3 \\
Bi Doup/Gia Rich & 111 & 154 & 7 & 7 & 919 & 1 \\
Cong Troi & 61 & 84 & 5 & 4 & 529 & 4 \\
Nui Ba & 53 & 63 & 3 & 2 & 408 & 5 \\
Chu Yang Sin & 95 & 141 & 6 & 7 & 806 & 2 \\
\hline
\end{tabular}

${ }^{a} \mathrm{RRS}$, restricted-range species: a species with a global range of under $50,000 \mathrm{~km}^{2}$ (ICBP 1992).

${ }^{b} \mathrm{RDB}$, a species currently assigned an IUCN category of threat (Collar $e t$ al. 1994) but not including Near-threatened species.

five sites on the Plateau, four of which are in the Thuong Da Nhim and Chu Yang Sin Nature Reserves.

\section{Records of threatened and restricted-range bird species}

Detailed below are records of all bird species assigned an IUCN category of threat (after Collar et al. 1994) plus those previously considered threatened or Near-threatened (in Collar and Andrew 1988) but now judged to be "Low Risk" (M. J. Crosby in litt. 1994), which were recorded during this survey.

\section{Crested Argus Rheinardia ocellata ocellata}

This species is currently considered Vulnerable (Collar et al. 1994). Previously, three birds were heard on Nui Bi Doup on 22 and 23 May and two heard at Long Lanh $\left(12^{\circ} \mathrm{O} 8^{\prime} \mathrm{N} 108^{\circ} 39^{\prime} \mathrm{E}\right)$ on 24 May 1991 , which constituted a significant range extension and the first confirmed records for the Da Lat Plateau EBA (Eames and Robson 1992).

A single bird was heard calling at c.12hoo on Hill 1978 on 14 November 1993, and a single bird on Nui Bi Doup on 15 December; two birds were heard calling during the afternoon at Nui Gia Rich on 22 December and a single at 13 h45 at Nui Gia Rich on 23 December. Surprisingly, this species was not recorded on Chu Yang Sin although its range is well known to the north. It could occur at this site and birds may simply not have been calling.

\section{Red-vented Barbet Megalaima lagrandieri}

This species was listed as Near-threatened by Collar and Andrew (1988) but, since it is still widespread in Vietnam, it was recently down-graded to Low Risk (M. J. Crosby in litt. 1994). On the Da Lat Plateau, it had previously been recorded at several localities including Tuyen Lam Lake $\left(11^{\circ} 52^{\prime} \mathrm{N} 108^{\circ} 25^{\prime} \mathrm{E}\right)$ (Robson et al. 1993b).

A single bird was heard near Hill 1978 at $1,780 \mathrm{~m}$ on 16 and 17 November, and single birds were recorded on Nui Bi Doup at $1,880 \mathrm{~m}$ on 19 December, and at $1,430 \mathrm{~m}$ and 1,510 on 22 December 1993. On Chu Yang Sin one was heard at $1,540 \mathrm{~m}$ on 18 January and another heard below c.1,380 $\mathrm{m}$ on 25 January 
1994. These records all fall within the known altitudinal range of the species (50-1,900 m) given for Vietnam (Robson et al. 1989, 1993a,b).

\section{[Brown Hornbill Anorrhinus tickelli]}

This species is now considered Near-threatened (Collar et al. 1994). Hornbills, almost certainly this species, were heard on Nui Gia Rich on 22 December 1994.

\section{Pale-capped Pigeon Columba punicea}

This species is considered Vulnerable by Collar et al. (1994). It was previously recorded from central and south Annam and Cochinchina. In central Annam it was described as a common resident on the Quang Tri River (Delacour and Jabouille 1925). Around Pleiku it was described as sedentary and never very abundant (David-Beaulieu 1939). It was also obtained near Hue (Delacour et al. 1928). In south Annam it was collected near Djirling [Di Linh] (Delacour et al. 1928). In Cochinchina six specimens were obtained at Honquan, where it was described as rare (David-Beaulieu 1936). On the Da Lat Plateau, up to 14 birds were found feeding among fruiting trees amid old cultivation along the $\mathrm{Da}$ Dung River, north-west of Da Lat, on I June 1991; between eight and ten birds were seen at the same locality the following day (Eames and Robson 1992).

Single individuals were seen at Hill 1978 on 18 November and on Nui Bi Doup on 20 December 1993, which constitute the first records for Thuong Da Nhim Nature Reserve. This is the only protected area in Vietnam in which this species has so far been recorded.

\section{Blyth's Kingfisher Alcedo hercules}

This species is considered Vulnerable by Collar et al. (1994). It was recorded at Bao-Ha (Kinnear 1929) and Lai Chau and Lao Cai in Tonkin (Vo Quy 1975). In central Annam it was collected at Kon Ha Nung (Stepanyan et al. 1983) and in north Annam has recently been recorded at Cat Bin (Robson et al. 1991). A single bird was seen along the Khe Thuong, Bach Ma National Park, on 30 April 1991 (Eames and Robson 1992).

In Chu Yang Sin Nature Reserve a single individual was recorded along the Ea K'Tour at c.500 m on 11 January 1994. This sighting was close to the boundary of the nature reserve, where limited suitable habitat remained.

\section{Short-tailed Scimitar-babbler Jabouilleia danjoui}

This species is considered Vulnerable (Collar et al. 1994). The type-series was collected from the Lang Bian peaks between 8 and 27 April 1918 (Robinson and Kloss 1919). The type of $J$. d. parvirostris was collected at Bana, central Annam, on 14 August 1926 (Delacour 1927). This subspecies has more recently been recorded in the vicinity of "Pass 41 " and Lang Ka Kou, central Annam, and Son Tung, north Annam (Robson et al. 1989) and Bach Ma National Park (Robson et al. 1991). On Nui Bi Doup three birds were found on 22 May, and a family 
party of four birds was seen at Long Lanh east (Nui Gia Rich) on 24 May 1991 (Eames and Robson 1992).

At Hill 1978 one was heard on 14 November and two seen on 15 November 1993. On Nui Bi Doup one was seen and several heard around camp on 12 December and one was heard on Nui Gia Rich on 26 December 1993 (1,810 m). On Chu Yang Sin, one was seen on 14 January $(1,490 \mathrm{~m})$, two were seen on 16 January $(1,860 \mathrm{~m})$ and one was heard on 20 January $1994(1,360 \mathrm{~m})$. A bird giving an unusual rattle-like call was seen at $1,300 \mathrm{~m}$ on 29 January. The species was also heard at $800 \mathrm{~m}$ on 31 January 1994. These represent the lowest altitudes at which this species has been recorded.

\section{Black-hooded Laughingthrush Garrulax milleti}

This Vietnamese endemic is confined to south Annam and considered Vulnerable (Collar et al. 1994). The type-specimen was collected at $\mathrm{Da}$ Lat between 2 and 4 May 1918, with 1o additional specimens taken at Dran on 11 May 1918 (Robinson and Kloss 1919). This species was also collected at Di Linh (Delacour et al. 1928). A specimen was also recently collected in Gia Lai province, well to the north of the Da Lat Plateau (Stepanyan et al. 1983). A party of up to 10 birds was seen (at c. $1,500 \mathrm{~m}$ ) in evergreen forest at Cong Troi $\left(12^{\circ} \mathrm{og}^{\prime} \mathrm{N} 108^{\circ} 23^{\prime} \mathrm{E}\right.$ ) on 17 and 30 May; up to five birds at $1,500 \mathrm{~m}$ near Tuyen Lam Lake on 27 May and three nearby on 28 May; three at Nui Pantar $\left(11^{\circ} 29^{\prime} \mathrm{N}\right.$ $\left.108^{\circ} 06^{\prime} \mathrm{E}\right)(1,400 \mathrm{~m})$ on $6 \mathrm{June}$; and at least eight birds were seen and two or three additional flocks heard at Deo Nui San $\left(11^{\circ} 29^{\prime} \mathrm{N} 108^{\circ} 04^{\prime} \mathrm{E}\right)(\mathrm{c} .1,200 \mathrm{~m})$ on 7 June 1991 (Eames and Robson 1992). These were the first records of this species for 30 years (Brunel 1978).

A flock of 4-6 was seen at forest edge on Nui Gia Rich on 22 December 1993. On Chu Yang Sin, a flock was seen briefly at 1,000 m on 12 January 1994, with a flock of four at $1,430 \mathrm{~m}$. Two or three were heard at $1,330 \mathrm{~m}$, three were heard at $1,460 \mathrm{~m}$, and others were heard at $1,540 \mathrm{~m}$ on 18 January. Also on 18 January at least two flocks, one of three to five birds and the second of perhaps 8-10, were seen together with White-browed Scimitar-babblers Pomatorhinus schisticeps and Green Magpie Cissa chinensis. Two flocks were heard but not seen at c. $1,300 \mathrm{~m}$ on 20 January. The species was heard at 1,650 $\mathrm{m}$ on 22 January and below 1,380 m on 25 January. Four birds were seen together with White-browed Scimitar-babblers at $1,470 \mathrm{~m}$ on 23 January, and five were seen at c.1,000 $\mathrm{m}$ on 30 January. The species was heard and seen at $800 \mathrm{~m}$ on 31 January 1994, which represents the lowest elevations at which it has been recorded. Thus it is now known to occur in both the Thuong Da Nhim and Chu Yang Sin Nature Reserves.

\section{White-cheeked Laughingthrush Garrulax vassali}

This bird was considered Near-threatened by Collar and Andrew (1988) but subsequently down-graded to Low Risk (M. J. Crosby in litt. 1994). In Vietnam it was listed for central and south Annam by King et al. (1975) and there are recent records from Kon Cha Rang Nature Reserve, and Buon Luoi (Robson et al. 1989). On the Da Lat Plateau it was previously recorded from $\mathrm{Nui} \mathrm{Ba,} \mathrm{Cong}$ 
Troi and Long Lanh as well as a number of localities in the Di Linh area (Robson et al. 1993, 1994).

On Chu Yang Sin, a flock of at least 15 was seen at $1,700 \mathrm{~m}$ on 22 January and a flock of c.50 at 1,010 $\mathrm{m}$ on 29 January 1994. Described as an endemic resident above $600 \mathrm{~m}$ (King et al. 1975), this species was recently recorded at $1,900 \mathrm{~m}$ on Nui Ba (Robson et al. 1993a). The records from Chu Yang Sin therefore represent the second highest elevation at which it has been recorded. It had previously been recorded from Long Lanh in Thuong Da Nhim Nature Reserve but these constitute the first records from Chu Yang Sin Nature Reserve. Although Robson et al. (1993a) noted it in grass, scrub and evergreen forest edge, on Chu Yang Sin it was found only in evergreen forest.

\section{Spot-breasted Laughingthrush Garrulax merulinus annamensis}

This species is considered Near-threatened by Collar et al. (1994), the very distinct subspecies annamensis being endemic to the highlands of south Annam. The ranges of G. $m$. obscurus, which occurs in south-east Yunnan, China, northern Laos and north-west Tonkin, and G. $m$. annamensis are separated by c. $1,000 \mathrm{~km}$; but the songs of the two taxa are similar and perhaps only DNA hybridization can determine whether annamensis merits independent species status. This latter was previously recorded on the Da Lat Plateau at Tuyen Lam Lake and Long Lanh (Robson et al. 1993b).

On Chu Yang Sin, one was heard at c. $1,500 \mathrm{~m}$ on 20 January and a flock of four at $1,000 \mathrm{~m}$ on 30 January 1994. Although typically an inhabitant of evergreen forest edge in the vicinity of old swiddens (Robson et al. 1993b), the flock of four were seen around an old tree-fall but in closed-canopy evergreen forest.

\section{Collared Laughingthrush Garrulax yersini}

This Vietnamese endemic species is considered Vulnerable (Collar et al. 1994). The type-specimen was collected at Da Lat between 7 April and 4 May 1918 (Robinson and Kloss 1919) but more recently it has been recorded in dense forest at Man-Line near Da Lat (Brunel 1978). In 1991 two flocks of two and six birds were seen at Cong Troi on 19 May; several were heard on Nui Bi Doup, 22 and 23 May; up to 10 birds were seen at Long Lanh, 24 and 25 May; and several were heard on Nui Ba, 31 May (Eames and Robson 1992).

At Hill 1978 five were recorded on 15 November 1993, a single bird at 1,825 m, three at 2,020 $\mathrm{m}$ and two at $1,978 \mathrm{~m}$; in addition two further flocks of two and four were seen on 16 November. A flock of four and a flock of five were observed allopreening on 18 November. On Nui Bi Boup, two were seen at $2,130 \mathrm{~m}$ on 13 December, two at 2,015 $\mathrm{m}$ on 18 December, four at $1,860 \mathrm{~m}$ and five at $1,840 \mathrm{~m}$ on 19 December. One was heard on Nui Gia Rich at 1,780 $\mathrm{m}$ on 26 December. On Chu Yang Sin, flocks of five and two were seen on 16 January one heard at $1,55^{\circ} \mathrm{m}$ on 18 January, two were seen on 20 January and a single was heard at $1,670 \mathrm{~m}$ on 22 January, two were seen at 1,660 $\mathrm{m}$ on 24 January, with flocks of eight at $2,442 \mathrm{~m}$, three at $2,400 \mathrm{~m}$ and c. 10 at $2,405 \mathrm{~m}$ on 27 January 1994. This species is now known from both Thuong Da Nhim and Chu Yang Sin Nature Reserves. 


\section{Grey-crowned Crocias Crocias langbianis}

This bird is endemic to Vietnam and was considered Critical (Collar et. al 1994). The type-specimen was an adult male collected at Da Lat, Lang Bian Peaks, on 5 April 1938 by B. Björkegren. Two females were collected at the same locality on 12 April (Gyldenstolpe 1939).

The species was rediscovered on Chu Yang Sin at c.1615 m on 29 January 1994. Two birds were observed in a bird flock containing Green Magpie and Maroon Oriole Oriolus trailli, at 1,010 m (Eames 1994). Chu Yang Sin Nature Reserve is the only protected area from which this species is known (see Eames et al. 1995b).

\section{Yellow-billed Nuthatch Sitta solangiae fortior}

This species is endemic to Vietnam and Hainan Island (China), and considered Vulnerable (Collar et al. 1994). The type-specimen was obtained at Loquiho near Sa Pa, Tonkin, in October 1929 (Delacour and Jabouille 1931). The race S. s. fortior was described from a male collected on the Lang Bian Peaks, Da Lat, on 14 March 1939 (Delacour and Greenway 1939). In Vietnam the species is known only from these two areas. In 1991 at least three were seen at Cong Troi on 17 and 30 May; several at Cong Troi on 19 May; several at Nui Bi Doup on 22 and 23 May; at least six at Long Lanh on 24 May; up to 10 near Tuyen Lam Lake on 27 and 28 May; and at least four on Nui Ba on 31 May (Eames and Robson 1992).

A single bird and later two were in a bird flock on Hill 1978 on 18 November 1993. One was recorded on Nui Gia Rich $(1,610 \mathrm{~m})$ on 22 December. On Chu Yang Sin, two were recorded at $1,330 \mathrm{~m}$ on 13 January 1994, while two at $1,100 \mathrm{~m}$ on 30 January were at the lowest altitude at which this species has been observed. On the Da Lat Plateau, it had previously been found between 1,450 and 2,100 $\mathrm{m}$ (Robson et al. 1993b). Thuong Da Nhim and Chu Yang Sin Nature Reserves are the only protected areas from which this subspecies is known.

\section{Vietnamese Greenfinch Carduelis monguilloti}

This Vietnamese endemic was not listed by Collar and Andrew (1988) but has recently been designated Near-threatened (Collar et al. 1994). The type-series was collected at Da Lat on 11 October 1925 (Delacour 1926) and the species was recorded as far south as Di Linh (Delacour et al. 1928). Recent observations have determined that the species is common throughout the Da Lat Plateau (Robson et al. 1991). A flock of 10 birds, including juveniles, was observed flycatching airborne termites from Pinus kesiya at Da Lat on 16 May. Several others were noted $17 \mathrm{~km}$ south of Da Lat on 18 May, at Cong Troi on 19 May, and at Tuyen Lam Lake on 27 May. This species was also noted on the lower slopes of Nui Bi Doup and at Long Lanh between 21 and 25 May 1991 (Eames and Robson 1992).

Two were heard in flight at Hill 1978 on 15 November and five on 18 November 1993. The species was heard flying over Nui Bi Doup at 1,740 $\mathrm{m}$ on 20 December. Interestingly this species was not recorded during the survey of 
Chu Yang Sin Nature Reserve. Thuong Da Nim Nature Reserve is therefore the only protected area from which the species has been recorded.

\section{Threats to biodiversity on the Da Lat Plateau}

\section{Shifting cultivation}

The traditional occupation of the tribal communities living on the plateau is shifting cultivation, which is believed to have greatly modified the extent, composition and quality of natural vegetation. This has had and will continue to have major implications for biodiversity conservation (see below). However, during this survey no active shifting cultivation was noted in the study areas.

\section{Migration}

In 1980 a Communist Party Congress decision was taken to assist, under a planned programme, the transfer of people from overcrowded lowland areas to the largely "underpopulated" high plateaus in the centre and south of the country in order to develop "New economic zones" (Sargent 1991). Thousands of people, both as part of this scheme and as spontaneous migrants, emigrate each year to relatively resource-rich provinces such as Dak Lak. Krong Bong district (in which Chu Yang Sin is located) continues to receive immigrants, who place ever greater demands on ever diminishing land and water resources. The dry deciduous and semi-evergreen forests along the Ea Krong Ana River have now been almost entirely destroyed, which will increasingly lead to new communities meeting their fuelwood and timber needs from the evergreen forests within Chu Yang Sin Nature Reserve.

\section{Urban expansion}

The city of Da Lat is the major centre of human population and the only centre of urban expansion on the Plateau. The city's northern suburbs are adjacent to the southern extremity of the Nui Ba-Nui Bi Doup sector of the Thuong Da Nhim Nature Reserve. In 1970 the population of Da Lat was 89,656, while in 1992 it stood at 120,559 (Truong Tro et al. 1993). The area of settlement has grown from perhaps one $\mathrm{km}^{2}$ in 1919 to $16 \mathrm{~km}^{2}$ in 1993 .

\section{Forest policy}

Logging continues to be a major activity on the Da Lat Plateau. Much of the pine forest is allocated to production forest. The forests of Thuong $\mathrm{Da}$ Nhim and Chu Yang Sin Nature Reserves are allocated to Special-Use Forests which is the category principally for environmental conservation but which also permits use for tourism, defence, educational purposes and other unspecified special uses. Protection Forest is a category principally for watershed protection and watershed erosion control, but some logging is permitted. As long as a forest is assigned to Protection Forest it remains vulnerable to commercial exploitation, and indeed this has been the case until recently at Nui Gia Rich (see below). 


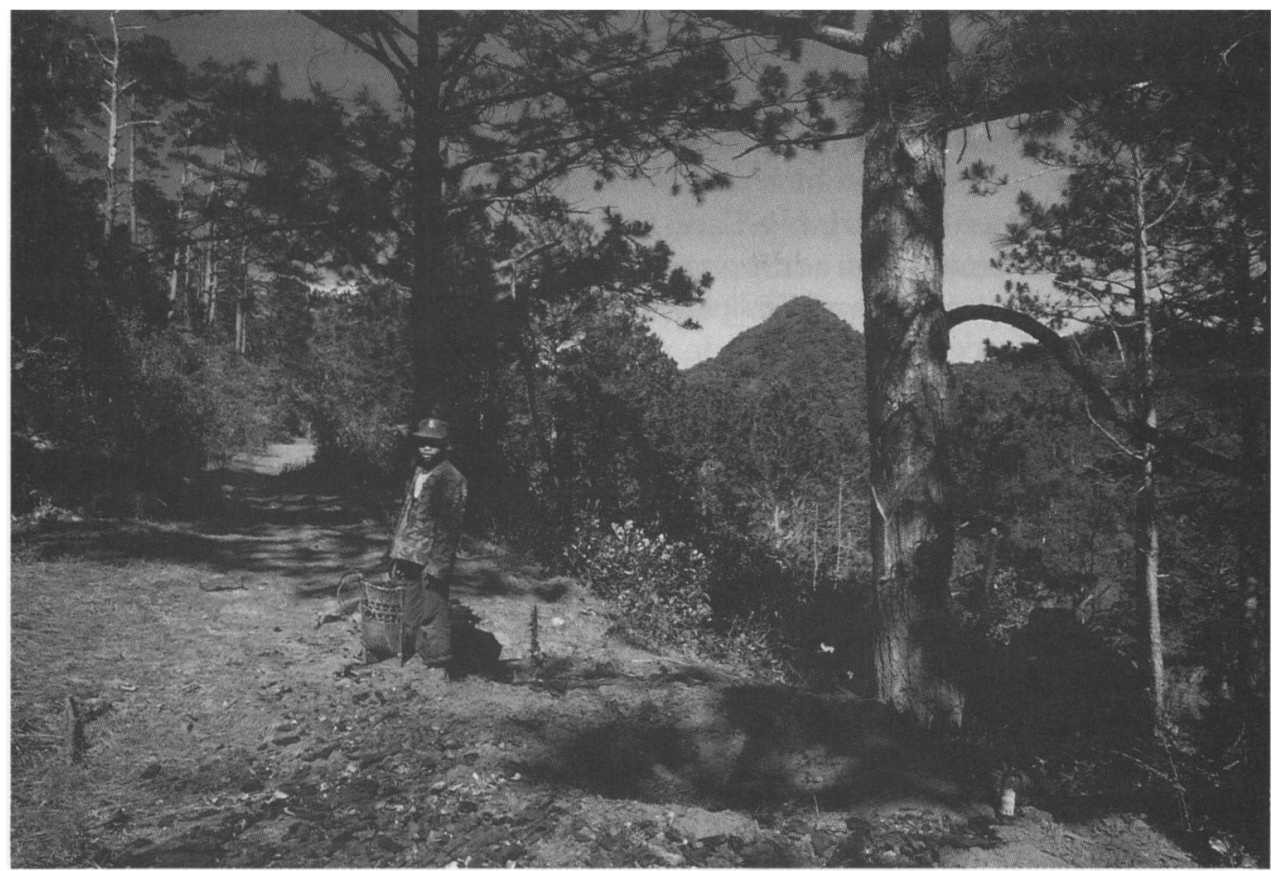

Figure 4. A charcoal-maker standing next to his recently excavated kiln. In the background one of the two summits of Nui Ba is clearly visible.

\section{Charcoal and fuelwood collection}

The growth and size of Da Lat's human population have a number of implications for protected area establishment. Much of the fuelwood needs of Da Lat are met by the remaining evergreen forest of Nui Ba. An occupation of the tribal villages located between $\mathrm{Da}$ Lat and $\mathrm{Nui} \mathrm{Ba}$ is charcoal production and fuelwood collection. Charcoal kilns are excavated and constructed in the forest on Nui Ba and the sacks of charcoal transported to Da Lat daily (Figure 4). In 1991, 100 loads of charcoal and 35 loads of firewood were counted in a single morning on their way to Da Lat (Robson et al. 1991). If this is typical and the size of each load is $0.25 \mathrm{~m}^{3}$ then this represents a loss of at least $34.5 \mathrm{~m}^{3}$ of evergreen forest per day, which is not sustainable from an area of evergreen forest estimated to cover a mere 300 ha, only around half of which was judged to be undamaged (Robson et al. 1991). The continued growth in population of $\mathrm{Da}$ Lat is likely to lead to increased fuelwood demands resulting ultimately in the complete destruction of the evergreen forests of Nui $\mathrm{Ba}$.

\section{Non-fuel and non-timber forest products}

Pine resin extracted from Pinus kesiya, which is an essential ingredient used in the manufacture of turpentine, is widely tapped from pine forests throughout Lam Dong province. It is not known to what extent resin extraction occurs within the Thuong Da Nhim or Chu Yang Sin Nature Reserves, but it is known to have at least formerly occurred on Nui Ba. There is some evidence of trade 
in other essential oils collected from Cinnamomum and Illicium species in the Thuong Da Nhim area.

There appears to be an increasing trade in some flowering plants, especially in certain members of the Orchidaceae. In Da Lat there is a widespread trade in wild-collected material which can be bought easily in the city market. Even at remote settlements like Long Lanh, tribal women routinely collect and sell orchids to local dealers. In addition, there is an unquantified trade in wildlife trophies in Da Lat and Bao Loc, principally for sale to local tourists. Bao Loc appears to be the centre of the trade with at least three shops devoted exclusively to the sale of wildlife products.

\section{Discussion}

\section{The biodiversity value of Thuong Da Nhim and Chu Yang Sin Nature Reserves}

The global importance of the Da Lat Plateau as one of 221 centres of bird endemism (EBAs) has already been established earlier in this paper, and indeed formed part of the justification for the BirdLife Vietnam Programme. A cornerstone of the EBA concept is that within these areas there are high levels of endemism amongst other taxa and that therefore, in the many areas where other taxa have yet to be evaluated taxonomically and distributionally, "endemic" birds can be used as good first indicators of biodiversity.

Fieldwork located all four species of endemic bird whose global ranges are confined to the Da Lat Plateau, and identified four other restricted-range bird species whose global distributions extend over a greater area. On the basis of endemism, and by considering degree of threat and overall species and taxonomic diversity, we can rank our results to indicate the most important areas on the Plateau which should be a focus for conservation action.

It can be seen from Table 2 that Nui Bi Doup/Nui Gia Rich and Chu Yang Sin are the richest areas in terms of endemic birds and in terms of overall species number, and each scored more than twice as high as Nui Ba. It is also important to note that of the four restricted-range species confined to this EBA, three are found in each of Nui Bi Doup/Nui Gia Rich and Chu Yang Sin, but Vietnamese Greenfinch was found only at the former and Grey-crowned Crocias only at the latter. There is no reason, however, why both species should not occur in both nature reserves.

We can conclude from this that the Nui Bi Doup/Nui Gia Rich and Chu Yang Sin are the richest areas and should form the core areas of Thuong Da Nhim and Chu Yang Sin Nature Reserves. Hill 1978 and Cong Troi should also be included in any strict nature reserve. The low score obtained for Nui Ba reflects the degraded condition of its forests, its small overall size and its isolation from other areas of evergreen forest (see Figure 3). Consideration should be given to excluding this area from the Thuong Da Nhim Nature Reserve.

Four bird species previously recorded on the Da Lat Plateau and presently assigned an IUCN category of threat (Collar et al. 1994), were not recorded during the survey. These comprise Sarus Crane Grus antigone (Near-threatened), Green Peafowl Pavo muticus (Vulnerable), Germain's Peacock-pheasant Polyplectron germaini (Vulnerable) and Green Cochoa Cochoa viridis (Near-threatened). 
The record of Sarus Crane may refer to a migrant or wandering individual but it is possible that the species formerly bred on the Plateau (Delacour and Jabouille 1931). Green Peafowl was formerly recorded from Di Linh and certainly bred in the area, as Delacour collected two young females (Delacour and Jabouille 1931). As an inhabitant of drier, deciduous and semi-evergreen forests it probably never had an extensive range on the Plateau. It has recently suffered a catastrophic reduction in numbers and range size in Vietnam and its continued presence on the Plateau is doubtful. Germain's Peacock-pheasant is endemic to southern Vietnam and its altitudinal range extends onto the Plateau, where it was first collected at Di Linh (Delacour and Jabouille 1931) and subsequently seen on Nui Pantar at c.1,100 m on 6 June 1991 (Eames and Robson 1992). This may be the upper limit of the species's altitudinal range, as no evidence has yet been obtained from higher elevations. Green Cochoa was first recorded from Nui Ba and has been heard there subsequently (Delacour and Jabouille 1931, Robson et al. 1994). It is a shy and rare species, and it was not surprising that it was missed during this survey. However, males were subsequently recorded on 10 March 1995 along the Da Kmemp just outside Chu Yang Sin Nature Reserve, and on 1 and 3 April 1995 at 1,000 $\mathrm{m}$ inside the same reserve. The species probably occurs at low density throughout the Plateau, and it seems unlikely that the loss of Nui Ba from the Thuong Da Nhim Nature Reserve would compromise the bird's future in the region.

\section{Economic value as watershed protection}

The economic value of Thuong Da Nhim and Chu Yang Sin Nature Reserves is principally due to the vital contribution these forests make to watershed protection. Such values are hard to quantify, but the following example well illustrates the point that natural forests can, if left undisturbed, indirectly contribute substantially to the local and national economy every year.

The Da Nhim hydro-electric plant uses water from the Don Duong Lake in the watershed of the Da Nhim and Klong Klet Rivers. Part of the watersheds of these rivers lie in the Thuong Da Nhim Nature Reserve. In 1989 total national electricity generation was estimated at 28,614.2 million MJ (Nguyen Trong Dieu 1992). The contribution of the $\mathrm{Da}$ Nhim hydro-electric project to the national grid amounted to $13 \%$ of national output. Since completion, erosion within the watershed has resulted in deposition in the lake, reducing capacity from $165.1^{6} \mathrm{~m}^{3}$ to $157.1^{6} \mathrm{~m}^{3}$. Accumulated sedimentation within the lake in the first 26 years of operation (to 1987 ) has amounted to $7,800,000 \mathrm{~m}^{3}$, an average $300,000 \mathrm{~m}^{3} /$ year, which has reduced output capacity by 56.1 million MJ. As a result of damage to the turbines caused by soil and rock debris, electricity generation is interrupted for about 10-15 days per annum for repairs. In 1990 the repairs cost 100 million dong (US\$9,000). The major reason cited for loss of generation capacity and damage to the turbines is deforestation leading to erosion in the Da Nhim and Klong Klet watersheds (Lam Dong People's Committee 1990). Therefore the protection of the forests of the upper $\mathrm{Da}$ Nhim watershed is vital to maintain the economic viability of the Da Nhim hydro-electric scheme.

Chu Yang Sin lies in the watershed of the upper Mekong. The Ea K'Tour, Ea Krong Ana and Dak Krong Kno rivers all flow into the Serepok River, which is 
one of the major tributaries of the Mekong rising in Vietnam. The value of this watershed is not easily quantifiable, but is likely to be of major economic importance since the Mekong Delta is the richest agricultural area in Vietnam.

\section{Economic value of tourism}

Tourism is a rapidly expanding sector of the Vietnamese economy and is one of the main elements in the economy of Da Lat. Forested montane vistas and fresh mountain air attract thousands of visitors every year. The outstanding natural beauty of much of the Da Lat Plateau undoubtedly offers a potential for tourist development, particularly for the specialist international market. This type of tourist enjoys unspoilt mountain scenery, wilderness areas and wildlife, combined with interesting local culture. All these elements are present in Thuong Da Nhim and Chu Yang Sin Nature Reserves. However, this specialist tourist market is limited and is unlikely to provide a major economic panacea for the region. It is important that any future tourist development in these nature reserves is strictly controlled and permitted only in a manner compatible with and sympathetic to biodiversity conservation.

\section{Present nature reserve size, shape and boundaries}

In Vietnam, protected areas are often too small to support viable populations of the larger mammals and birds they were designed and established to protect. Under existing proposals Thuong Da Nhim and Chu Yang Sin Nature Reserves share extensive common boundaries. Irrespective of the fact that they are under three provincial authorities, their combined area of c.117,716 ha forms one of the largest protected area complexes in Vietnam.

However, critical points for consideration are whether the current boundaries and area adequately include all representative habitats over the full altitudinal range, and whether there is sufficient contiguity of habitat within this protected area complex fully to conserve the general area's endemic avifauna (see below).

The evergreen forests in Chu Yang Sin Nature Reserve range from 500 to $2,442 \mathrm{~m}$ and encompass the altitudinal requirements of all the bird species listed in Table 2. However, on Nui Ba and Nui Bi Doup most of the remaining evergreen forest occurs above $1,500 \mathrm{~m}$, which is at the upper altitudinal limit for Crested Argus and Black-hooded Laughingthrush. Below this elevation forests comprise either Pinus kesiya or have been cleared for agriculture.

At present the watershed of the middle $\mathrm{Na} \mathrm{Nhim}$ is excluded from the protected area, but is depicted as the Da Nhim Watershed Protection Forest in both Figures 2 and 3. This forest area is composed mainly of Pinus kesiya. The inclusion of some of these forests could reduce the length of the southern boundary significantly and could link more fully with the Phuoc Binh sector in Ninh Thuan province. Their total exclusion from the adjoining nature reserves is compatible with biodiversity conservation but they should continue to be designated as Watershed Protection Forests.

Some ambiguity surrounds the current status of forests at Dac Dung. Although depicted as Special Use Forest (i.e. nature reserve or national park) on current Lam Dong Forest Protection Department maps, they are excluded 
from the Nui Bi Doup-Nui Ba Nature Reserve declaration signed by Lam Dong People's Committee on 22 October 1993. These forests must, however, be included in the Thuong Da Nhim Nature Reserve to ensure that a contiguous protected area exists between Chu Yang Sin and Thuong Da Nhim Nature Reserves.

Another area excluded from the current proposal is the evergreen forests of Cong Troi. The need to include these forests in a protected area has already been identified (Eames and Robson 1992) and can only be emphasized again here. If Thuong Da Nhim Nature Reserve was extended west to include Cong Troi, the boundary of the south-west arm of the reserve could be modified to exclude areas of lower biodiversity value which would additionally reduce the overall length of the reserve boundary and improve the area-to-boundary ratio. Furthermore, it would eliminate the need to devote scarce financial and human resources to protecting an area of relatively low biodiversity value where human utilization of resources is high and likely to increase as the population and area of Da Lat City increases.

In the Phuoc Binh sector of Thuong Da Nhim Nature Reserve, the forests to the north-west which have the highest biodiversity value, such as those around Hill 1978, are contiguous with the evergreen forests in Lam Dong and should form a core of the reserve area and be managed as a strict nature reserve. The area designated for protection in Tinh Thuan is 25,866 ha, which comprises a mosaic of forest types reflecting a history of human use. The provincial boundary forms the reserve boundary in the north and east. The southern boundary is formed by the Da May and To Hap Rivers, which joins an arbitrarily drawn line running east to west (Figure 2). Clearly, this will need revision to delineate a boundary more suitable for conservation, which should ideally follow a natural landscape feature. The forests of this area are poorly documented and would benefit from survey to determine their biological value and where the appropriate boundary should be.

Kanh Hoa province is also likely to support evergreen forests representative of the Da Lat Plateau EBA, but no proposals have yet been made for the inclusion of any forest areas in this province in a nature reserve. Since Kanh Hoa shares a common border with Lam Dong and Ninh Thuan the identification and survey of evergreen forest in Kanh Hoa is a logical next step (Figure 1).

\section{Habitat contiguity and present land-use practices}

Although we will never be certain, it seems highly probable that, before the arrival of man, evergreen forests were once contiguous across the entire plateau (except on exposed, well-drained slopes with a rainfall of less than $1,500 \mathrm{~mm}$, which probably supported stands of Pinus kesiya). Shifting cultivation has reduced the absolute area of evergreen forest and led to its fragmentation. Most remaining areas of evergreen forest are on mountains and steep slopes which enjoy higher annual precipitation and are more difficult to cultivate (Figure 5).

It has been shown that small fragments of habitat, isolated due to environmental modification, function like "islands" and will lose some of their original species until a new equilibrium is reached, depending on the size, richness and diversity of the area and its degree of isolation from other similar habitats 


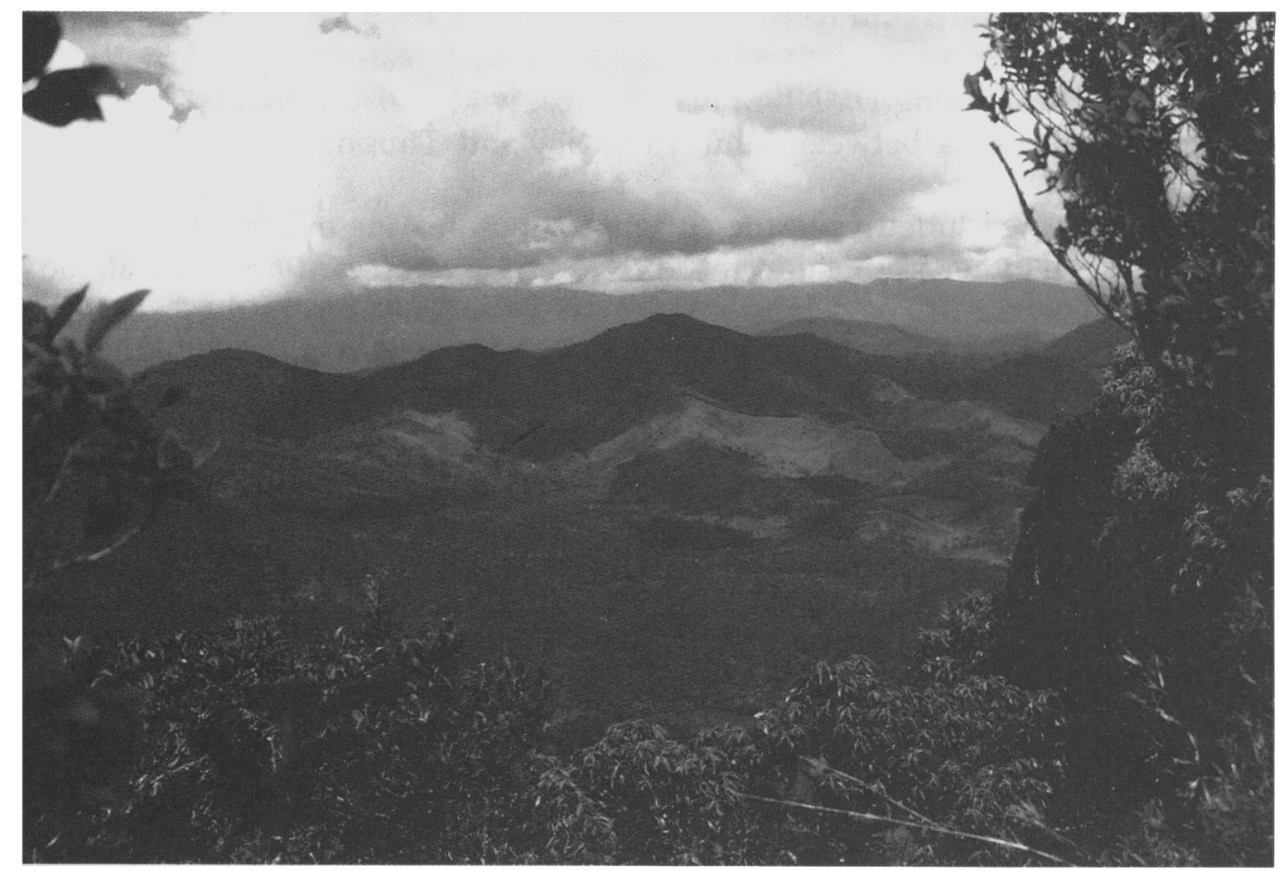

Figure 5. A view from the summit trail on Nui Bi Doup showing an extensive area of evergreen forest in the foreground. In the middle distance shifting cultivation has created a mosaic of vegetation types comprising seral stages.

(MacKinnon et al. 1986). As yet, we have no data on whether the contiguity of evergreen forest in the nature reserves is sufficient to support viable populations of representative biota, including the restricted-range bird species characteristic of the EBA. It is possible that the extinction process may already be advanced for the fragmented and isolated populations of Crested Argus, a terrestrial species with limited dispersive ability, which is dependent on evergreen forest. During the survey this species was recorded at only two sites (Hill 1978 and Nui Bi Doup), which are largely separated by suboptimal habitat (i.e. Pinus kesiya forest).

The frequent use of fire as a tool in shifting cultivation prevents the regeneration of evergreen forest and promotes the growth of a fire-climax dominated by Pinus kesiya. This is now the most widespread forest type on the Plateau, covering an estimated 120,000 ha (Shiva 1990). The bird community of Pinus kesiya forest is greatly impoverished in comparison with evergreen forest (Figure 6). Of a total of 212 bird species recorded during the survey only six resident forest bird species were found predominantly in Pinus kesiya forest, these being Grey-faced Woodpecker Picus canus, Oriental Scops Owl Otus sunia, Slender-billed Oriole Oriolus tenuirostris, Eurasian Jay Garrulus glandarius, Chestnut-vented Nuthatch Sitta nagaensis and Green-backed Tit Parus monticolus. Two other species with an inferred association with Coniferae, Red Crossbill Loxia curvirostra and Vietnamese Greenfinch, were often recorded in mixed forests, or cultivation in the case of the latter. Three species, Eastern Grass Owl Tyto longimembris, Pale-footed Bush-warbler Cettia pallidipes and Russet Bush-warbler Bradypterus seebohmi, showed a clear association with grassland, whilst a number of others, including Chinese Francolin Francolinus pintadeanus, Black-collared Starling Sturnus nigri- 


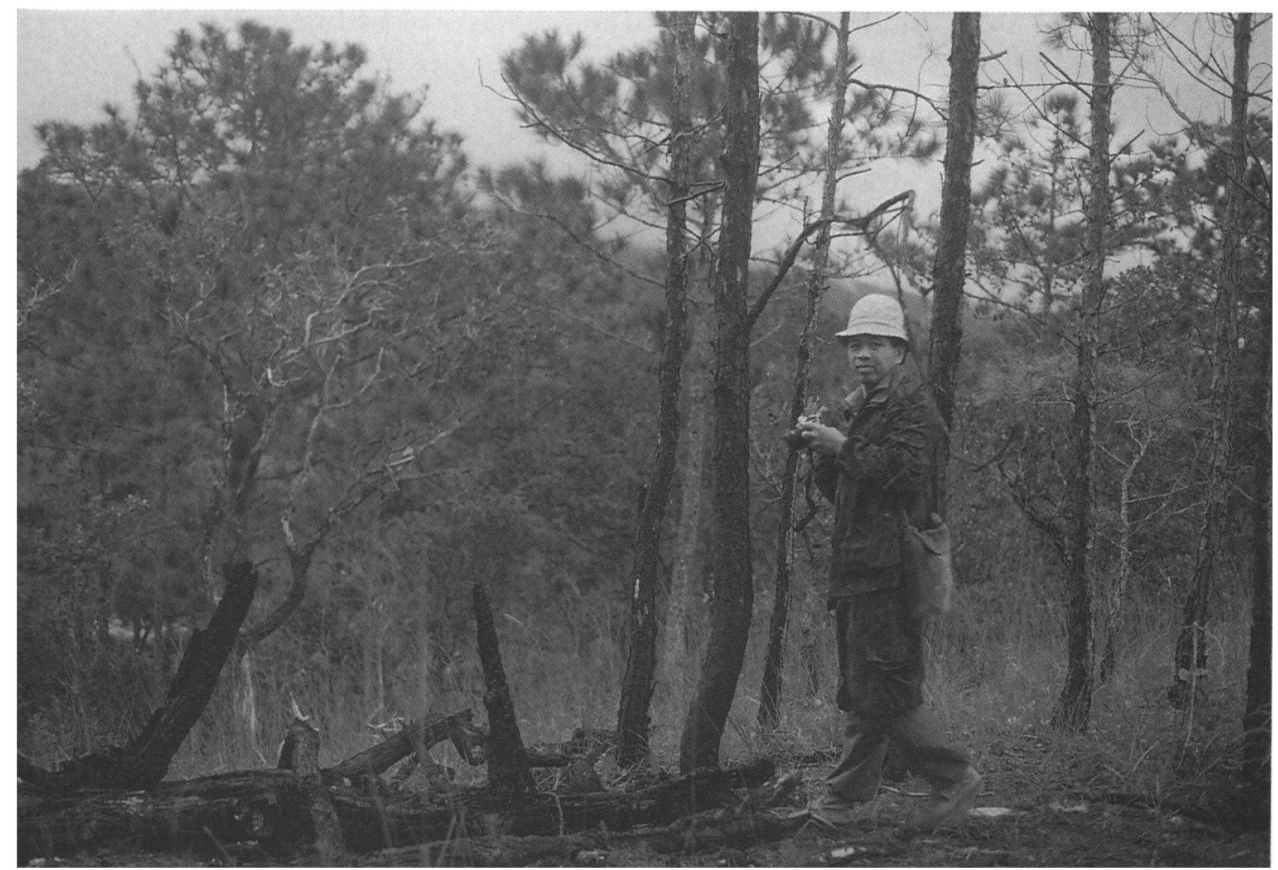

Figure 6. Pinus kesiya is the most widespread forest type on the Da Lat Plateau. Since it is a monoculture with a simple structure, it supports only an impoverished bird community. Frequent burning prevents regeneration of an evergreen shrub layer and thus maintains this fire-climax.

collis and Scaly-breasted Munia Lonchura punctulata, occurred in grassland, scrub and cultivation. The majority - comprising some 200 species or nearly $95 \%$ - were found exclusively or predominantly in evergreen forest formations.

Since areas supporting evergreen forest are preferred by shifting cultivators, owing to the higher humus content and lower acidity of the soil and thus its greater fertility, shifting cultivation poses a continuous threat to evergreen forest and de facto to biodiversity conservation, since the evergreen forest has a high and the pine forest a low biodiversity value.

Some bird species, notably widespread forest-edge specialists such as Vinousbreasted Starling Sturnus burmannicus and Grey Bushchat Saxicola ferrea together with the pine forest species, probably benefit from habitat modification. It is possible that two Near-threatened species, Spot-breasted Laughingthrush (which shows a liking for evergreen forest edge, especially in the vicinity of old swiddens) and Vietnamese Greenfinch, may have undergone population increases as a result of forest clearance. Nevertheless, the overwhelming majority of species, including all the globally threatened species, are birds of evergreen forest and must have undergone population declines since forest clearance began on the Plateau.

However, Pinus kesiya is a pioneer species so that, providing the forest is not burnt, evergreen species will colonize the understorey. Unfortunately, much of the pine forest understorey on the Plateau is burnt annually. The abolition of this single practice would be a major benefit to biodiversity conservation by ultimately increasing the area under evergreen forest (Figure 6). 


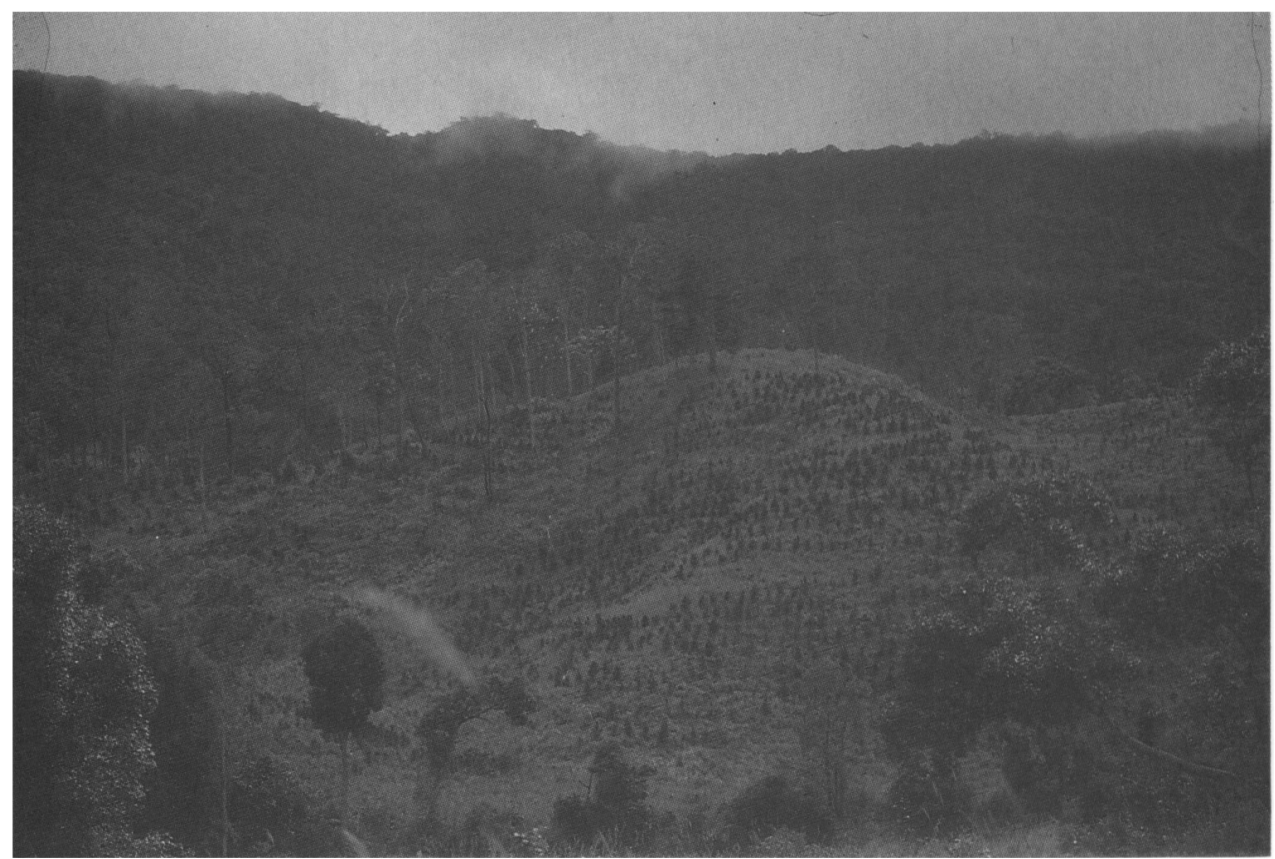

Figure 7. Reforestation with Pinus kesiya at Long Lanh. Sympathetically managed, this activity could assist the regeneration of evergreen forest and prevent its further fragmentation.

Reforestation programmes, such as that at Long Lanh, should be encouraged but the trees should not be harvested from designated areas: instead, ecological succession should be permitted so that eventually the forests of Nui Gia Rich can link with other evergreen forest areas (Figure 7). It should be a goal of forest management to reduce further fragmentation of evergreen forest by establishing corridors of Pinus kesiya forest to link areas of evergreen forest.

Commercial forestry practices in the recent past in the Nui Gia Rich and Hill 1978 areas have focused on the selective extraction of commercially valuable species such as Fokinia hodginsii. A network of logging roads has been built along ridges in evergreen forest to facilitate the extraction of this prized species, resulting in the destruction of much evergreen forest. Fortunately, this activity now appears to have ceased. The practice is incompatible with both biodiversity conservation and watershed protection, and it must not be permitted in the nature reserves.

Charcoal production has resulted in the destruction of much of the evergreen forest on Nui Ba (Figure 4). At the scale at which it is practised, it is clearly incompatible with biodiversity conservation. Efforts to regulate or eliminate it are, however, likely to be very costly in terms of both human and financial resources.

The current land-use practice within Chu Yang Sin appears to be benign neglect, which is highly compatible with biodiversity conservation! At Chu Yang Sin there are low levels of human forest utilization, and this should be main- 
tained. Efforts should be made to reduce and restrict the numbers of settlers into districts adjacent to the protected area so as to prevent future encroachment on the nature reserve.

\section{Options for land use and buffering}

We currently have insufficient data on the distribution of human settlements in the overall area to advance any prescription for zonation. The demographic situation in the three areas appears to be quite different in each. Lam Dong province supports the highest number of people living in the protected area, particularly in the Long Lanh area. These are tribal communities, either still practising shifting cultivation or partially settled. Concentric zoning is unlikely therefore to be the appropriate model for implementation in these areas, and is likely only to lead to conflict of interests.

Since we are principally interested in the conservation of biodiversity, areas of evergreen forest must be the focus for conservation action. An option for achieving this could be through a balance of small strict reserves in larger areas of partial reserves. In practice this would mean designating the areas of evergreen forest as strict nature reserves where no human use would be permitted, except perhaps the collection of minor forest products for subsistence purposes only.

As habitat fragmentation is a threat to biodiversity on the Plateau, corridors linking areas of evergreen forest should be developed. The best means by which to achieve this is the elimination of shifting cultivation, prevention of fire and cessation of logging in designated corridor areas. Ecological succession will ensue and over time the stands of Pinus kesiya will develop an understorey of evergreen species. Eventually this will produce a mixed forest and ultimately a predominantly evergreen forest. This process of habitat restoration will occur naturally but in some very degraded areas can be assisted with reforestation with Pinus kesiya.

Remaining areas of pine forest would be available for controlled human use such as commercial forestry and gardens for shifting cultivators. These two practices, if conducted in a controlled and limited manner, could promote bird diversity because they generan edge habitats and create early successional stages, thereby providing niches for some pioneer species. Commercial logging in stands of Pinus kesiya must be ecologically sympathetic, which will probably require the modification of some silvicultural practices. These should include leaving standing "over-mature" trees, which are not commercial timber trees and often play critical roles in maintaining biological cycles. They should be specially protected during logging operations and should not be eliminated by post-logging silvicultural practices (Sayer 1991).

Human immigration into the Thuong Da Nhim and Chu Yang Sin Nature Reserves should not be permitted, nor should the establishment of any new settlements. The protected area authorities should investigate measures to improve the quality of life of the indigenous communities in ways which are consistent with the attaintment of biodiversity conservation objectives. Local minority people should be favoured for employment opportunities in the protected areas once they are established. 


\section{Recommendations}

We now face a unique opportunity on the Da Lat Plateau to create a major protected area of international importance. Not only is the area of high global conservation importance but it is also of high hydrological and potential tourist value. Unlike most areas in Vietnam the area comprises extensive primary forest habitats with relatively low levels of human population density and resource utilization.

The principal recommendations of this paper are as follows:

1. In light of the high levels of bird and plant endemism in Thuong Da Nhim and Chu Yang Sin and because of their great hydrological value, the Ministry of Forestry should proceed with the production of management plans for the three reserve components and their gazettement as a matter of priority.

2. The long-term strategy should be the management of the two nature reserves as a unified protected area. This can be achieved by coordinated land-use management between the three provinces.

3. The primary land-use management strategy should be to conserve the remaining areas of evergreen forest and increase its extent through sympathetic forestry practices.

4. In all three reserve sectors in the provinces concerned there should be thorough ground-truthing to ensure the most appropriate boundaries for conservation are established and that these take into account patterns of human settlement and land use.

\section{Acknowledgements}

I would like to extend my thanks to the following individuals and institutions for providing help and assistance. In the Ministry of Agriculture and Rural Development particular thanks to Mr Nguyen Mau Tai, Director of the Forest Protection Department, Mr Bui Xuan Yen, Director of the International Cooperation Department, Mr Tran Dinh Dan, Vice-Director of the Forest Protection Department, Dr Nguyen Nhu Phuong, Chief, Management of National Forest Parks, Nature Reserves and Wildlife, Mr Pham Mong Giao, Senior Expert of Biology and Dr Nguyen Huu Dong, Director of Forest Resources and Environment Centre of Forest Inventory and Planning Institute for providing a counterpart, Nguyen Ngoc Chinh.

Thanks to Professor Dr Dang Huy Huynh, former Director of the Institute of Ecology and Biological Resources, Hanoi, for permitting the secondment of Dr Nguyen $\mathrm{Cu}$ to the project.

In Dak Lak province I would like to thank Mr Y Ly Nie Kdam, Vice-Chairman of Dak Lak People's Committee, Mr Nguyen Cong Ba, Director, and Mr Ha Cong Tuan, Vice-Director of the Agriculture and Forestry Department, Mr Ngo Quang Quy, Vice-Director of the Forest Planning and Inventory Office, the People's Committee of K'rong Bong district, Mr Ama Pec, Chairman and people of Chu Pui Sub-district especially Ama Dinh, Ma Da, Ma Guan, Ama Gam, Ama Hien, Y Hien, Ma Phien, Ma Tia, Ma Sa and Ma Vinh. For assistance in Lam Dong province I would like to thank the People's Committee of Lam Dong province, Da Nhim Watershed Management Staff, Lam Dong Forest Protection 
Department especially Mr Hoang Ba Pho, Vice-Director of the Agriculture/ Forestry and Water Department and Chairman of the Provincial Forest Protection Department, Mr Bui Thanh Phong, Forest Engineer, Mr Nguyen Van Quy, Forest Engineer, Mr Dinh Van Ty, Lac Xuan Sub-district, Don Duong district, $\mathrm{Mr} \mathrm{Tu}$, the leader of Da Chay Sub-district, and People of Long Lanh Village including $\mathrm{Ha} \mathrm{Ba}$, Ha Chai, Ha Lang, Ha Giang, Ha Khiem, Ha Ni, Ha Nam and Ha Nhung. In Ninh Thuan province thanks to Ninh Thuan Agriculture/ Forest Department, Mr Tran Xuan Hoa, Vice-Director of the Agriculture/Forest Department, and Mr Tran Hong Chut, Head of Phuoc Binh Forest Watershed Management Staff.

At the University of Da Lat thanks to Mr Nguyen Trong Phuong, Dean of the Faculty of Biology, for permitting the secondment of two members of his staff to the project. Dr Nguyen Dang Khoi, Director, and his staff for making our stay at the Da Lat Sub-Institute of Biology so enjoyable. At the Sub-Institute of Ecology and Biological Resources, Saigon, Professor Dr Doan Canh, Director, for permitting the secondment of his staff to the project.

At the Institute of Geography Professor Dr Nguyen Tran Cau, Vice-Director, Head of Cartography Division, and his staff for producing the maps, especially Nguyen Cam Van. I would like to thank the project team Dr Nguyen $\mathrm{Cu}, \mathrm{Vu}$ Ngoc Long, Nguyen Duy Chinh, Nong Van Tiep, Ngoc Quang Quy, Nguyen Van Quy, Tran Hong Chut for their dedication, hard work, and for being such good company. Finally, particular thanks to Shanthini P. Dawson for assisting in the preparation of this paper.

The fieldwork which facilitated this work formed part of the World Wide Fund for Nature Vietnam Programme and was also undertaken as part of the BirdLife International Vietnam Programme which is supported by the European Union.

\section{Appendix 1. A provisional list of restricted-range bird taxa occurring on the Da Lat Plateau.}

This list comprises restricted-range bird taxa recorded on the Da Lat Plateau. It is based on distributions given in Howard and Moore (1994), Delacour and Jabouille (1931), Vo Quy $(1975,1981)$. The sequence of species follows Sibley and Monroe (1990) and the taxonomy follows Howard and Moore (1994). Thus some taxa listed by Delacour and Jabouille (1931) such as Large Niltava Niltava grandis decorata are excluded because they are not recognized by Howard and Moore (1980). The only exception is the inclusion of the newly described subspecies of Spectacled Fulvetta Alcippe ruficapilla bidoupensis. The definition of a restricted-range taxon is the same as used in ICBP (1992). The list should be treated as provisional because of the poorly known distributions of most of these taxa. $C$, taxon confined to the Da Lat Plateau; $O$, taxon with a restricted range occurring on the $\mathrm{Da}$ Lat Plateau but with a wider geographical distribution in Indochina.

Arborophila rufogularis annamensis Rufous-throated Partridge C A. brunneopectus albigula Bar-backed Partridge C Lophura nycthemera annamensis Silver Pheasant $\mathrm{O}$ Polyplectron germaini Germain's Peacock-pheasant 
Rheinardia ocellata ocellata Crested Argus O

Picoides hyperythrus annamensis Rufous-bellied Woodpecker $\mathrm{O}$

Picus chlorolophus krempfi Lesser Yellownape $\mathrm{O}$

Blythipicus pyrrhotis annamensis Bay Woodpecker $\mathrm{O}$

Megalaima franklinii auricularis Golden-throated Barbet $O$

M. oorti annamensis Black-browed Barbet $\mathrm{O}$

Harpactes erythrocephalus annamensis Red-headed Trogon $\mathrm{O}$

Pitta oatesi bolovenensis Rusty-naped Pitta $\mathrm{O}$

Cissa chinensis margaritae Green Magpie C

Oriolus chinensis invisus Black-naped Oriole $\mathrm{O}$

O. traillii robinsoni Maroon Oriole $\mathrm{O}$

Brachypteryx leucophrys langbianensis Lesser Shortwing O

Ficedula hyperythra annamensis Snowy-browed Flycatcher $\mathrm{O}$

F. westermanni langbianus Little Pied Flycatcher $\mathrm{O}$

Enicurus maculatus robinsoni Spotted Forktail C

Sitta solangiae fortior Yellow-billed Nuthatch $\mathrm{O}$

Certhia discolor meridionalis Brown-throated Treecreeper $\mathrm{C}$

Parus monticolus legendrei Green-backed Tit C

Sylviparus modestus klossi Yellow-browed Tit C

Aegithalos concinnus annamensis Black-throated Tit $\mathrm{O}$

Pericrocotus solaris deignani Grey-chinned Minivet $\mathrm{O}$

$P$. ethologus annamensis Long-tailed Minivet $\mathrm{O}$

Rhipidura albicollis cinerascens White-throated Fantail $\mathrm{O}$

Pycnonotus flavescens sordidus Flavescent Bulbul $O$

Hypsipetes mcclellandii griseiventer Mountain Bulbul C

Phylloscopus reguloides ticehursti Blyth's Crowned Warbler C

$P$. davisoni klossi White-tailed Leaf-warbler C

Seicercus castaniceps annamensis Chestnut-crowned Warbler C

Garrulax milleti Black-hooded Laughingthrush C

$G$. vassali White-cheeked Laughingthrush $\mathrm{O}$

G. merulinus annamensis Spot-breasted Laughingthrush C

G. yersini Collared Laughingthrush $C$

Pomatorhinus hypoleucos brevirostris Large Scimitar-babbler O

$P$. schisticeps annamensis White-browed Scimitar-babbler $\mathrm{O}$

$P$. ochraceiceps alius Red-billed Scimitar-babbler $\mathrm{O}$

Jabouilleia danjoui danjoui Short-tailed Scimitar-babbler C

Napothera brevicaudata rufiventer Streaked Wren-babbler O

$N$. epilepidota clara Eye-browed Wren-babbler $\mathrm{O}$

Pnoepyga pusilla annamensis Pygmy Wren-babbler $\mathrm{O}$

Stachyris ruficeps pagana Rufous-capped Babbler C

S. nigriceps rileyi Grey-throated Babbler $\mathrm{O}$

Leiothrix argentauris cunhaci Silver-eared Mesia O

Cutia nipalensis legalleni Cutia C

Pteruthius flaviscapis annamensis White-browed Shrike-babbler $\mathrm{O}$

$P$. aenobarbus indochinensis Chestnut-fronted Shrike-babbler $\mathrm{C}$

Minla cyanouroptera orientalis Blue-winged Minla C

Alcippe castaneceps klossi Rufous-winged Fulvetta C

A. ruficapilla bidoupensis Spectacled Fulvetta C 
A. peracensis annamensis Mountain Fulvetta $\mathrm{O}$

Crocias langbianus Grey-crowned Crocias C

Heterophasia annectans eximia Rufous-backed Sibia C

H. melanoleuca robinsoni Black-headed Sibia C

Paradoxornis gularis margaritae Grey-headed Parrotbill C

Aethopyga gouldiae annamensis Gould's Sunbird O

A. saturata johnsi Black-throated Sunbird C

A. nipalensis ezrai Green-tailed Sunbird

Arachnothera magna remota Streaked Spiderhunter $\mathrm{O}$

Carduelis monguilloti Vietnamese Greenfinch C

Loxia curvirostra meridionalis Red Crossbill C

Appendix 2. List of birds recorded at Thuong Da Nhim and Chu Yang Sin Nature Reserves.

The taxonomy and sequence of species follows Sibley and Monroe (1990).

Key: R, Restricted-range species. 1, Hill 1978; 2, Nui Bi Doup, Nui Gia Rich; 3 , Chu Yang Sin (Dak Lak); 4, Nui Bi Doup, Nui Gia Rich ${ }^{a}$; 5, Cong Troi ; 6. Nui $\mathrm{Ba}^{a} .{ }^{a}$ Recorded in 1991 (Eames and Robson 1992).

Francolinus pintadeanus Chinese Francolin 1, 2

Arborophila rufogularis Rufous-throated Partridge $1,2,3,5,6$

A. brunneopectus Bar-backed Partridge 1,2,3,5

Gallus gallus Red Junglefowl 3

Lophura nycthemera Silver Pheasant 1,2,5,6

Rheinardia ocellata Crested Argus R,1,2

Turnix suscitator Barred Buttonquail 2,5

Picumnus innominatus Speckled Piculet 2,3

Picoides canicapillus Grey-capped Woodpecker 2,6

Celeus brachyurus Rufous Woodpecker 2

Dryocopus javensis White-bellied Woodpecker 2

Picus chlorolophus Lesser Yellownape 3

$P$. flavinucha Greater Yellownape 1,2,3,5

$P$. canus Grey-faced Woodpecker 2

Chrysocolaptes lucidus Greater Flameback 2

Blythipicus pyrrhotis Bay Woodpecker 1,2,3,5,6

Hemicircus canente Heart-spotted Woodpecker 3

Megalaima lagrandieri Red-vented Barbet 1,2,3

M. faiostricta Green-eared Barbet 3

M. franklinii Golden-throated Barbet 1,2,3

M. oorti Black-browed Barbet $1,2,3,5,6$

M. incognita Moustached Barbet 2,5,6

Ptiloaemus tickelli Brown Hornbill (2)

Harpactes erythrocephalus Red-headed Trogon $1,2,3$

Eurystomus orientalis Dollarbird 2

Alcedo hercules Blyth's Kingfisher 3

Alcedo atthis Common Kingfisher 2

Halcyon smyrnensis White-throated Kingfisher 3 
Ceryle lugubris Crested Kingfisher 3

Nyctyornis athertoni Blue-bearded Bee-eater 1,2,3,5

Cuculus micropterus Indian Cuckoo 5

Surniculus lugubris Drongo Cuckoo 6

Phaenicophaeus tristis Green-billed Malkoha $\quad 1,2,3$

Centropus sinensis Greater Coucal 1,2,3

C. bengalensis Lesser Coucal 1,2,3

Loriculus vernalis Vernal Hanging Parrot 3

Psittacula alexandri Red-breasted Parakeet 1,2,3

$P$. finschii Grey-headed Parakeet 1

Apus nipalensis House Swift $1,2,3,5,6$

Tyto longimembris Eastern Grass Owl 4

Otus spilocephalus Mountain Scops-owl 1,3

O. sunia Oriental Scops-owl I

O. lempiji Collared Scops-owl 2

Strix leptogrammica Brown Wood-owl 1,2

Glaucidium brodiei Collared Owlet 1,2,3,5

G. cuculoides Asian Barred Owlet (2)

Caprimulgus indicus Grey Nightjar 3

Columbia punicea Pale-capped Pigeon 1,2

Streptopilia chinensis Spotted Dove 1,2,3

Macropygia unchall Barred Cuckoo-dove 1,4,5,6

Ducula badia Mountain Imperial Pigeon 1,2,5

Scolopax rusticola Eurasian Woodcock 2

Larus ridibundus Black-headed Gull 2

Aviceda jerdoni Jerdon's Baza 6

Elanus caeruleus Black-shouldered Kite 2

Spilornis cheela Crested Serpent-eagle 2,3,5

Accipiter trivirgatus Crested Goshawk 1,2,3,5

A. badius Shikra 1,2,5

A. virgatus Besra 5

Butastur indicus Grey-faced Buzzard 2,6

Spizaetus cirrhatus Changeable Hawk-eagle 2,3

Ictinaetus malayensis Black Eagle 1,2,3,5,6

Hieraeetus kienerii Rufous-bellied Eagle 4

Egretta garzetta Little Egret 2

E. alba Great Egret 2

Ardeola sp. 2,3

Pitta oatesi Rusty-naped Pitta 3

$P$. cyanea Blue Pitta 2,3

Psarisomus dalhousiae Long-tailed Broadbill 1,2,5

Culicicapa ceylonensis Grey-headed Canary Flycatcher 1,2,3,5,6

Irena puella Asian Fairy-bluebird (3)

Chloropsis hardwickei Orange-bellied Leafbird 1,3

Lanius collurioides Burmese Shrike 2,(3)

Garrulus glandarius Eurasian Jay 2,5

Cissa chinensis Green Magpie 1,2,3,6

C. hypoleuca Yellow-breasted Magpie 5 
Artamus fuscus Ashy Wood-swallow 2

Oriolus tenuirostris Slender-billed Oriole 4

O. traillii Maroon Oriole 1,2,3,5

Coracina macei Large Cuckoo-shrike 1,2,5

C. polioptera Indochinese Cuckoo-shrike 2

Pericrocotus solaris Grey-chinned Minivet 1,2,3,5

P. ethologus Long-tailed Minivet 1,2,3,5,6

$P$. flammeus Scarlet Minivet 3

Hemipus picatus Bar-winged Flycatcher-shrike 2

Rhipidura albicollis White-throated Fantail $1,2,3,6$

Dicrurus leucophaeus Ashy Drongo 1,2,3,5,6

D. aeneus Bronzed Drongo 3

D. remifer Lesser Racket-tailed Drongo 2,3,5

D. paradiseus Greater Racket-tailed Drongo 3

Hypothymis azurea Black-naped Monarch 3

Terpsiphone paradisi Asian Paradise-flycatcher

Aegithina tiphia Common Iora 3

A. lafresnayei Great Iora 3

Tephrodornis virgatus Large Wood-shrike 2

Monticola solitarius Blue Rock-thrush 2

Myiophoneus caeruleus Blue Whistling-thrush 2,3,5

Zoothera citrina Orange-headed Thrush 3

Z. marginata Dark-sided Thrush 3

Z. sibirica Siberian Thrush 2

$Z$. dauma Scaly Thrush 3

Turdus obscurus Eye-browed Thrush 2

Brachypteryx leucophrys Lesser Shortwing 2,3,5,6

$B$. montana White-browed Shortwing 3

Muscicapa latirostris Asian Brown Flycatcher (3)

Ficedula strophiata Rufous-gorgeted Flycatcher 2,3,5,6

F. parva Red-breasted Flycatcher I

F. solitaria Rufous-browed Flycatcher 2,3,5

F. hyperythra Snowy-browed Flycatcher $1,2,3,5,6$

F. westermanni Little Pied Flycatcher $2,3,5,6$

Eumyias thalassina Verditer Flycatcher $\mathbf{1 , 2 , 5 , 6}$

Niltava grandis Large Niltava 1,2,3,5,6

Cyornis rubeculoides Blue-throated Flycatcher 3

Erithacus calliope Siberian Rubythroat 2

Rhyacornis fuliginosus Plumbeous Water-redstart 1

Luscinia cyane Siberian Blue Robin 3

Copsychus saularis Oriental Magpie-robin 3

C. malabaricus White-rumped Shama 3

Cinclidium leucurum White-tailed Robin $1,2,3$

Enicurus schistaceus Slaty-backed Forktail 1,2,3,5

E. leschenaulti White-crowned Forktail 3

E. maculatus Spotted Forktail 1,2,3

Cochoa viridis Green Cochoa 6

Saxicola maura Siberian Stonechat 2 
S. ferrea Grey Bushchat $1,2,3,5,6$

Sturnus malabaricus Chestnut-tailed Starling 2

S. nigricollis Black-collared Starling $1,2,3,6$

S. burmannicus Vinous-breasted Starling 2

Gracula religiosa Hill Myna I

Sitta nagaensis Chestnut-vented Nuthatch $1,2,3,5$

$S$. solangiae Yellow-billed Nuthatch $R, \mathbf{1}, 2,3,5,6$

Certhia discolor Brown-throated Treecreeper 1,2,3,5,6

Parus monticolus Green-backed Tit 2,5,6

$P$. spilonotus Yellow-cheeked Tit 1,2,3,5,6

Sylviparus modestus Yellow-browed Tit 1,2,3,5

Aegithalos concinnus Black-throated Tit 1,2,3,5,6

Hirundo rustica Barn Swallow 1,2,3

H. striolata Striated Swallow 2,3

Delichon dasypus Asian House-martin 3

Pycnonotus melanicterus Black-crested Bulbul 3

$P$. jocosus Red-whiskered Bulbul 1,2,3,5

$P$. aurigaster Sooty-headed Bulbul 3,6

$P$. flavescens Flavescent Bulbul 1,2,5,6

Alophoixus ochraceus Ochraceous Bulbul 1,2,3

Hemixos flavala Ashy Bulbul 1,2,3

Hypsipetes mcclellandii Mountain Bulbul 1,2,3,5,6

H. leucocephalus Black Bulbul 1,2,3,5,6

Cisticola exilis Bright-capped Cisticola 2

Prinia atrogularis Hill Prinia $1,2,3,5,6$

$P$. inornata Plain Prinia $1,2,3$

$P$. flaviventris Yellow-bellied Prinia 2,(3)

Tesia cyaniventer Grey-bellied Tesia $1,2,3,5,6$

Urosphena squamiceps Asian Stubtail 1,2,3

Cettia pallidipes Pale-footed Bush-warbler 2

Bradypterus seebohmi Russet Bush-warbler 1,2,5

Orthotomus atrogularis Dark-necked Tailorbird 3

O. cucullatus Mountain Tailorbird 2,3,5,6

Phylloscopus davisoni White-tailed Leaf-warbler $1,2,3,5,6$

$P$. reguloides Blyth's Leaf-warbler 1,2,3,5,6

P. maculipennis Ashy-throated Warbler 1,2,3

$P$. borealis Arctic Warbler 2,3

$P$. inornatus Inornate Warbler 2,3

$P$. fuscatus Dusky Warbler 2

$P$. coronatus Eastern Crowned Warbler 2

Seicercus castaniceps Chestnut-crowned Warbler $1,2,3,5,6$

S. affinis White-spectacled Warbler $1,2,3,5,6$

Garrulax milleti Black-hooded Laughingthrush $\mathrm{R}, 2,3,5$

$G$. vassali White-cheeked Laughingthrush $R, 2,3,5$

G. merulinus Spot-breasted Laughingthrush $1,2,3,5$

G. yersini Collared Laughingthrush $\mathrm{R}, 1,2,3,5,6$

Pellorneum albiventre Spot-throated Babbler 2,5,6

Trichastoma tickelli Buff-breasted Babbler 3 
Malacopteron cinereum Scaly-crowned Babbler 3

Pomatorhinus schisticeps White-browed Scimitar-babbler $1,2,3,5,6$

P. ochraceiceps Red-billed Scimitar-babbler (2),3,5

$P$. hypoleucos Large Scimitar-babbler 2,3 Jabouilleia danjoui Short-tailed Scimitar-babbler R,1,2,3

Napothera brevicaudata Streaked Wren-babbler 3

$N$. epilepidota Eye-browed Wren-babbler 2,3

Pnoepyga pusilla Pygmy Wren-babbler 1,2,3,5,6

Stachyris ruficeps Rufous-capped Babbler 2,3,5,6

S. nigriceps Grey-throated Babbler 2,3,5,6

Macronous gularis Striped Tit-babbler 2

Leiothrix argentauris Silver-eared Mesia 2,5,6

Cutia nipalensis Cutia $1,2,3,5,6$

Pteruthius flaviscapis White-browed Shrike-babbler $1,2,3,5,6$

$P$. aenobarbus Chestnut-fronted Shrike-babbler $1,2,3,5,6$

Minla cyanouroptera Blue-winged Minla $1,2,3,5,6$

Alcippe castaneceps Rufous-winged Fulvetta $1,2,3,5,6$

A. ruficapilla bidoupensis Spectacled Fulvetta 2,3

A. peracensis Mountain Fulvetta $1,2,3,5,6$

Crocias langbianis Grey-crowned Crocias $R, 3$

Heterophasia annectans Rufous-backed Sibia 3

H. melanoleucos Black-headed Sibia 1,2,3,5,6

Yuhina zantholeuca White-bellied Yuhina 1,2,3,5,6

Y. nigrimenta Black-chinned Yuhina 3

Paradoxornis gularis Grey-headed Parrotbill 3,5

Dicaeum chrysorrheum Yellow-vented Flowerpecker 3,5

D. ignipectus Fire-breasted Flowerpecker 2,3

Aethopyga gouldiae Gould's Sunbird 1,2,3,5,6

A. nipalensis Green-tailed Sunbird 3

A. siparaja Crimson Sunbird (3)

Arachnothera longirostra Little Spiderhunter 3

A. magna Streaked Spiderhunter 1,2,3,5

Passer montanus Eurasian Tree-sparrow 1,2,3

Motacilla cinerea Grey Wagtail 2

Anthus rufulus Paddyfield Pipit 2,6

A. hodgsoni Olive Tree-pipit 1,2,6

Lonchura striata White-rumped Munia 2,3,5

L. punctulata Scaly-breasted Munia (1),2,(3),5,6

Carduelis monguilloti Vietnamese Greenfinch $R, 1,2,5,6$

Loxia curvirostra Red Crossbill 1,2,6

\section{References}

Brunel, J. (1978) Les oiseaux de la région du Lang-Bian, massif montagneux de la chaine Annamitique. Oiseaux et R.F.O. 48: 53-63.

Campbell, D. G. and Hammond, H. D., eds. (1989) Floristic inventory of tropical countries. New York: New York Botanical Garden.

Collar, N. J. and Andrew, P. (1988) Birds to watch: the ICBP checklist of threatened birds.

Cambridge, U.K.: International Council for Bird Preservation. 
Collar, N. J., Crosby, M. J. and Stattersfield, A. J. (1994) Birds to watch 2: the world list of threatened birds. Cambridge, U.K.: BirdLife International (BirdLife Conservation Series No. 4).

Collins, N. M., Sayer, J. A. and Whitmore, T. C., eds. (1991) The conservation atlas of tropical forests: Asia and the Pacific. London: Macmillan.

David-Beaulieu, E. (1936) Notes d'Annam. Oiseaux et R.F.O. 6: 162-163.

David-Beaulieu, E. (1939) Les oiseaux de la région de Pleiku (hauts plateaux de sud-Annam). Oiseaux et R.F.O. 9: 13-32, 163-182.

Delacour, J. (1926) [New birds from Indo-China.] Bull. Brit. Orn. Club 47: 8-22.

Delacour, J. (1927) [New birds from Indo-China.] Bull. Brit. Orn. Club 47: 151-170.

Delacour, J. (1929) On the birds collected during the fourth expedition to French IndoChina. Ibis (12)5: 193-220, 403-429.

Delacour, J. and Greenway, J. C. (1939) Seven new races from Indo-China. Bull. Brit. Orn. Club 59: 130-134.

Delacour, J. and Jabouille, P. (1925) On the birds of Quangtri, central Annam, with notes on others from other parts of French Indochina. Ibis (12)1: 209-260.

Delacour, J., Jabouille, P. and Lowe, W. P. (1928) On the birds collected during the third expedition to French Indo-China. Ibis (12)4: 23-51.

Delacour, J. and Jabouille, P. (1931) Les oiseaux de l'Indochine française, 1-4. Paris: Exposition Coloniale Internationale.

Eames, J. C. (1994) Little-known Oriental bird: Grey-crowned Crocias Crocias langbianis. Oriental Bird Club Bull. 19: 20-23.

Eames, J. C. and Nguyen Cu (1994) A management feasibility study of Thuong Da Nhim and Chu Yang Sin Nature Reserves on the Da Lat Plateau, Vietnam. Unpublished WWF report to Ministry of Forestry, Hanoi.

Eames, J. C. and Robson, C. R. (1992) Forest bird surveys in Vietnam. Cambridge, U.K.: International Council for Bird Preservation (Study Report 51 ).

Eames, J. C., Robson, C. R. and Nguyen Cu (1995a) A new subspecies of Spectacled Fulvetta Alcippe ruficapilla from Vietnam. Forktail 10: 141-157.

Eames, J. C., Le Trong Trai and Nguyen Cu (1995b) Rediscovery of the Grey-crowned Crocias Crocias langbianis. Bird Conserv. Internatn. 5: 525-535.

Gyldenstolpe, N. (1939) On a remarkable new shrike from southern Annam. Ark. Zool. 31B(3): $1-3$.

Howard, R. and Moore, A. (1994) A complete checklist of the birds of the world. Second edition. London: Academic Press.

ICBP (1992) Putting biodiversity on the map: priority areas for global conservation. Cambridge, U.K.: International Council for Bird Preservation.

King, B. F., Dickinson, E. C. and Woodcock, M. W. (1975) A field guide to the birds of South-East Asia. London: Collins.

Kinnear, N. B. (1929) On the birds collected by Mr H. Stevens in northern Tonkin in 1923-24. Ibis (12)5: 107-130, 292-344.

Lam Dong People's Committee (1990) Investment Project: Establishment of a Protection Forest in catchment basin of Da Nhim Hydroelectric Reservoir. Da Lat: unpublished report to the Council of Ministers, State Planning Committee and Ministry of Forestry.

MacKinnon, J. (1990) Forestry sector review, tropical forestry action plan, Vietnam: the nature conservation system, national parks and protected areas. Hanoi, Vietnam: Ministry of Forestry, UNDP, FAO.

MacKinnon, J. (1993) Biodiversity action plan for Vietnam (draft). Unpublished report to International Union for Conservation of Nature and Natural Resources.

MacKinnon, J. and MacKinnon, K. (1986) Review of the protected areas system in the IndoMalayan Realm. Gland, Switzerland, and Cambridge, U.K.: International Union for Conservation of Nature and Natural Resources. 
MacKinnon, J., MacKinnon, K., Child, G. and Thorsell, J. (1986) Managing protected areas in the tropics. Gland, Switzerland: International Union for Conservation of Nature and Natural Resources.

Moorman, F. R. (1961) Republic of Vietnam general soil map. Da Lat, Vietnam: National Geographic Service of Vietnam.

Nguyen Trong Dieu (1992) Geography of Vietnam. Hanoi, Vietnam: The Gioi, Foreign Languages Publishing House.

Pham Ngoc Toan and Phan Tat Dac (1978) Khi Hau Vietnam. Hanoi, Vietnam: Nha xuat ban khoa hoc va ky thuat.

Reynolds, R. T., Scott, J. M. and Nussbaum, R. A. (1980) A variable circular-plot method for estimating bird numbers. Condor 82: 309-313.

Robinson, H. C. and Kloss, C. B. (1919) On birds from South Annam and Cochin-China. Ibis (11)1: 392-453.

Robson, C. R., Eames, J. C., Wolstencroft, J. A., Nguyen Cu and Truong Van La (1989) Recent records of birds from Vietnam. Forktail 5: 71-97.

Robson, C. R., Eames; J. C., Newman, M., Nguyen Cu and Truong Van La (1991) Vietnam Forest Project Forest Bird Surveys 1989/90, Final Report. Unpublished report to ICBP.

Robson, C. R., Eames, J. C., Nguyen Cu and Truong Van La (1993a) Further recent records of birds from Vietnam. Forktail 8: 25-52.

Robson, C. R., Eames, J. C., Nguyen Cu and Truong Van La (1993b) Birds recorded during the third BirdLife/Forest Birds Working Group expedition in Vietnam. Forktail 9: 89-119.

Sargent, C. (1991) Forestry sector review, tropical forestry action plan, Vietnam: land use issues. Hanoi, Vietnam: Ministry of Forestry, UNDP, FAO.

Sayer, J. (1991) Rainforest buffer zones: guidelines for protected area managers. Newbury, U.K.: International Union for Conservation of Nature and Natural Resources.

Shiva, M. P. (1990) Forestry sector review, tropical forestry action plan, Vietnam: non-wood forest products. Hanoi, Vietnam: Ministry of Forestry, UNDP, FAO.

Sibley, C. G. and Monroe, B. L., Jr. (1990) Distribution and taxonomy of birds of the world. New Haven: Yale University Press.

Stepanyan, L. S., Vo Quy, Nguyen Cu and Truong Van La (1983) Results of the research on composition and distribution of avifauna in region Kon Ha Nung (Tay Nguyen Plateau). Thong Bao Khon Hoc 1: 15-13.

Truong Tro, Do Van, Nguyen Huu Tranh, Nguyen Tuan Tai and Mai Thai Linh (1993) $\mathrm{Da}$ Lat than pho cao nguyen. Saigon, Vietnam: Uy ban Nhan dan thanh pho Da Lat. Nha xuat ban thanh pho Ho Chi Minh.

Udvardy, M. D. F. (1975) A classification of the biogeographical provinces of the world. IUCN Occasional Paper 18: $1-48$.

Vidal, J. (1960) La végétation du Laos. Toulouse: Souladoure.

Vo Quy (1975) Chim Viêt Nam, 1. Hanoi: Nha xuat ban khoa hoc va ky thuat.

Vo Quy (1981) Chim Viêt Nam, 2. Hanoi: Nha xuat ban khoa hoc va ky thuat.

Whitmore, T. C. (1992) An introduction to tropical rainforests. Oxford: Clarendon Press.

JONATHAN C. EAMES

BirdLife International Vietnam Programme, $17 M 13$ Lang Trung, Dong Da, Hanoi, Vietnam. 